\title{
CHANGES IN FUNDING PATTERNS BY LATIN AMERICAN BANIKING SYSTEMS: HOW LARGE? HOW RISKY?
}

Eiliana Rojas suarez and Jose Maria serena.

Documentos de Trabajo. N. 1521

\section{baNCo Gespaña}

\section{5}

\author{
Eurosistema
}


CHANGES IN FUNDING PATTERNS BY LATIN AMERICAN BANKING SYSTEMS:

HOW LARGE? HOW RISKY? 
CHANGES IN FUNDING PATTERNS BY LATIN AMERICAN BANKING SYSTEMS: HOW LARGE? HOW RISKY? ${ }^{(*}$

\author{
Liliana Rojas-Suárez \\ CENTRE FOR GLOBAL DEVELOPMENT \\ José María Serena \\ BANCO DE ESPAÑA
}


The Working Paper Series seeks to disseminate original research in economics and finance. All papers have been anonymously refereed. By publishing these papers, the Banco de España aims to contribute to economic analysis and, in particular, to knowledge of the Spanish economy and its international environment.

The opinions and analyses in the Working Paper Series are the responsibility of the authors and, therefore, do not necessarily coincide with those of the Banco de España or the Eurosystem.

The Banco de España disseminates its main reports and most of its publications via the Internet at the following website: http://www.bde.es.

Reproduction for educational and non-commercial purposes is permitted provided that the source is acknowledged.

C BANCO DE ESPAÑA, Madrid, 2015

ISSN: 1579-8666 (on line) 


\section{Abstract}

This paper investigates the shifts in Latin American banks' funding patterns in the postglobal financial crisis period. To this end we introduce a new measure of exposure of local banking systems to international debt markets that we term: International Debt Issuances by Locally Supervised Institutions. In contrast to well-known BIS measures, our new metric includes all entities that fall under the supervisory purview of the local authority. This is especially important in Latin America, where the participation of foreign banks that are established as independent, fully-capitalized entities is most substantial. Using this metric we found that all types of Latin American banking groups increased significantly and sharply their issuance of external debt securities. Owing to the low ratios of banks' external debt to total liabilities in the pre-crisis period, solid solvency ratios and improved supervisory capacity, the recent increase in banks' external indebtedness has not resulted in financial difficulties and banking systems remain strong. However, a preliminary analysis of risks based on this new trend reveals the emergence of several signs of increased vulnerability. First, in some banking groups (particularly in Brazilian banks, domestic and foreign alike) the increased issuance of external debt has been accompanied by a greater reliance on wholesale funding. In contrast, reliance on wholesale funding by Colombian banks has remained low and stable. Second, rollover risks have significantly increased for Latin American banking groups. Maturing debt, which increased significantly in 2013-14, will continue at high levels in 2015-16 in the context of major uncertainties in international capital markets. This risk is especially noticeable in Brazil and Chile, whose ratios of maturing debt to total debt are high. Third, in spite of a sizeable accumulation of international reserves, the large increase in banks' external debt might have contributed to reducing the resilience of central banks to deal with a severe adverse shock.

Keywords: emerging economies' banks, locally supervised institutions, international debt, wholesale funding, Latin America and financial fragilities.

JEL Classification: G15, G21, F36. 


\section{Resumen}

Este trabajo investiga los cambios en los patrones de financiación de los bancos de América Latina tras la crisis financiera global. Para ello introducimos una nueva medida de la exposición de los sistemas bancarios locales a los mercados internacionales de deuda: emisiones internacionales de deuda de las entidades supervisadas localmente. En contraste con las métricas del BPI habitualmente empleadas, la nuestra incluye todas las entidades que están bajo la supervisión de la autoridad local. Esto es especialmente importante en América Latina, donde la participación de los bancos extranjeros establecidos como entidades independientes y enteramente participadas es muy amplia. Empleando esta métrica, encontramos que todos los tipos de grupos bancarios aumentaron de modo significativo y acusado sus emisiones de deuda internacional. Debido a las bajas ratios de deuda externa de partida, sólidas ratios de solvencia y mejora en la capacidad supervisora, el reciente incremento en el endeudamiento externo de los bancos no ha llevado a dificultades financieras y los sistemas bancarios se mantienen sólidos. Sin embargo, un análisis preliminar de los riesgos de esta nueva tendencia muestra la emergencia de varios signos de vulnerabilidad. En primer lugar, en algunos sistemas bancarios (en particular, los bancos brasileños) el incremento en las emisiones de deuda se ha visto acompañado por mayor uso de financiación mayorista. En contraste, este se ha mantenido bajo y estable en los bancos colombianos. En segundo lugar, los riesgos de refinanciación han aumentado significativamente en los grupos bancarios latinoamericanos. Los vencimientos de deuda, que aumentaron notablemente en 2013-2014, se mantendrán en niveles elevados en 2015-2016, en un contexto de notables incertidumbres en los mercados internacionales. Este riesgo es particularmente notable en Brasil y en Chile. En tercer lugar, a pesar de la gran acumulación de reservas internacionales, el fuerte aumento en la deuda externa de los bancos puede haber contribuido a reducir la capacidad de los bancos centrales a enfrentarse a un shock externo adverso.

Palabras clave: bancos de economías emergentes, entidades bajo supervisión local, deuda internacional, financiación mayorista, América latina y fragilidades financieras.

Códigos JEL: G15, G21, F36. 
The recent literature on financial integration has emphasized recent changes in the external funding patterns of banks and corporations from emerging markets. In particular, significant attention has been given to the reduction in international bank borrowing and the large increase in debt securities issuance in international capital markets (see Turner, 2014 and Shin, 2013) that has taken place in the aftermath of the global financial crisis. For example, according to BIS data, while international loans to emerging markets reached US $\$ 150$ billion in 2010 , this figure was only US $\$ 59$ billion in 2013 , and was close to zero in the first half of 2014. In contrast, international debt securities issued by nationals from emerging markets almost doubled in the same period, increasing from US\$ 143 billion in 2010 to US $\$ 210$ billion in 2013. ${ }^{1}$ In spite of market stress, this trend continued in 2014.

Chart 1 illustrates the evolution of external sources of funding by emerging market economies in the last two decades. While access to international capital markets was severely limited in the late 1990s and early 2000s, debt securities financing and, especially, cross-border bank lending significantly increased in the period 2005 to mid-2008. These flows collapsed during the global financial crisis. However, while debt securities issuances have reached unprecedented levels in the most recent period, bank lending has been on a declining trend since 2010.

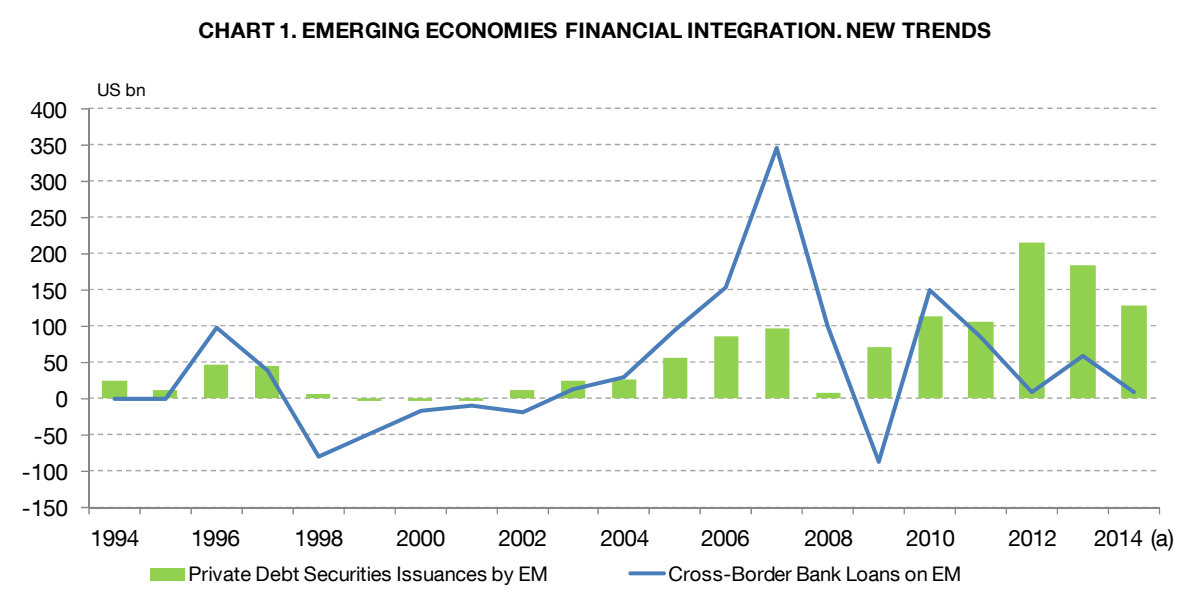

Source: BIS International Debt Securities Statistics, by Nationality; BIS international Banking

Statistics, by Residence; National Accounts

Taken together there are two factors that explain this shift. The first deals with the unprecedented expansionary monetary policy followed by advanced economies since the onset of the global financial crisis. The exceptionally low interest rates in these economies, especially in the US, induced international investors to increase their search for yield through purchases of debt securities issued internationally by entities from emerging markets, where yields are significantly higher. The increased demand for these securities resulted in an easier access to capital markets by emerging economies companies. ${ }^{2}$ Most

1. The BIS data on debt security issuances discussed here are on a nationality basis. This includes issuances by offshore subsidiaries of domestic entities. Thus, this is a measure of external indebtedness by emerging markets entities on a consolidated basis (see Shin, 2013).

2. International investors have also increased their demand for a variety of other emerging market assets negotiated in the local markets, including portfolio equity, which has contributed to significant increases in stock market prices in the local exchanges. This paper, however, focuses on issues related to international debt issuances. 
of these securities have been denominated in dollars (Gruic and Wooldridge (2013) and the large increase in private sector international issuances coincides with a period of abnormally low 10 years dollar term premium. ${ }^{3}$

The second reason relates to developments in the banking systems of advanced economies. The process of deleveraging to resolve banking difficulties combined with a significant tightening of regulations governing the activities of banks has resulted in a significant reduction of credit growth, especially to riskier borrowers; clients from emerging markets belong to this category. While the deleveraging process can be considered a temporary phenomenon, changes in the regulatory framework argue for a longer-term effect. ${ }^{4}$

The main purpose of this paper is to explore whether the observed shifts in external sources of funding to emerging markets are opening (or exacerbating) sources of financial risks in Latin America banking systems. ${ }^{5}$ By investigating this issue, the paper expands and complements recent work on emerging economies' financial integration trends after the global financial crisis. A number of papers have highlighted the shift towards market-based financing in international markets by non-financial corporations (IMF (2014b), Chui, Fender and Suskho (2014), CGFS-FSB-SCAV (2014), Fuertes and Serena (2014)). Regional analyses have identified a similar pattern in Latin American borrowers (IADB (2014), IMF (2014c) CLAAF (2013, 2014), and Rodriguez-Bastos et al. (2015)). A second strand of research has looked at the resilience of emerging economies banking systems, epitomized not only in robust domestic credit growth, but also on their incipient trend towards internationalization (CGFS (2014), Van Horen (2012)). ${ }^{6}$ Under this view, improved access to international debt markets can also provide an opportunity for Latin American banks to issue Basel III-compliant bonds - if appropriate for their business models--to meet capital requirements. ${ }^{7}$ However, the breadth of emerging economies banks' shift towards international debt-markets and the potential sources of vulnerability derived from this shift have not been investigated yet. This paper aims to fill this gap.

To assess potential sources of vulnerabilities in Latin American banking systems derived from recent trends in international capital markets, we first ask whether the postglobal crisis features of external indebtedness in Latin America differ from previous capital inflow episodes. We find that, although total net external financing as a ratio of GDP is similar in the pre- and post-global crisis periods and lower than in the mid-1990s - a pattern roughly similar to other Emerging Economies, there are two new features in Latin America: The first is that the participation of banks in total international debt securities issuances has increased

3. See Turner (2014), Bernake (2013), and McCauley et al. (2014).

4. Stricter financial regulatory changes in advanced economies resulted from authorities' recognition of the deficiencies in the pre-crisis regulatory framework that contributed to the eruption of the crisis. At the global level, the new recommendations of the Basel Committee on Banking Supervision for stricter capital and liquidity requirements are contained in Basel III. See http://www.bis.org/bcbs/basel3.htm. At the country/ regional level, there are particular specificities. For example, the European Union implemented in 2014 a new Capital Requirements Directive (CRD IV) that includes regulatory requirements stricter than Basel III and in 2010 the United States has passed new legislation under the so-called Dodd-Frank Act. See http://www.banking.senate.gov/public/ files/070110 Dodd Frank Wall Street Reform comprehensive summary Final.pdf. 5. The analysis of debt-generating inflows is extremely relevant for emerging markets, in general, and Latin America, in particular; the latter being known by the recurrence of financial/debt crises during the 1980, 1990s and early 2000s. As the ample literature on financial crises shows, a sudden stop of capital inflows, especially debt-generating flows, has often been the major trigger of severe financial difficulties (Calvo et al, 1996).

6. For more general analysis on emerging economies banking systems after the global financial crisis, see Claessens and Van Horen (2014). Rojas-Suarez (2007) and Galindo, Izquierdo, and Rojas-Suárez (2010) discuss relevant issues of Latin American banking systems, including the relative importance of foreign banks in each of the countries of the region. 7. These bonds, categorized as subordinated debt, are more likely to suffer losses when a bank experiences significant stresses than ordinary bonds. 
significantly, and abruptly, in the period after the global crisis; the suddenness of the increase indicating that the latter has not been the result of a process of banking sectors' deepening and development. This contrasts with other Emerging Economies where banks have been important players in the international debt markets since the 1990s. The second salient feature in Latin America is that the participation of sovereigns in total issuance of external debt securities has declined dramatically; a trend that started in the mid-2000s, reflecting improved fiscal management.

Should the rapid increase in banks' international debt securities issuances be a source of concern? Delving into this issue is not straightforward since none of the two aggregate measures produced by the BIS - the most important source of data for country comparisons of banks' international borrowing activities-includes simultaneously debt issuances by all the financial institutions that are under the surveillance responsibility of local banking supervisors. To tackle this constraint we use data at the security level to construct a new aggregate that we call international debt issuances by locally-supervised institutions. This metric includes international issuances of all banking groups (domestic and foreign-owned). That is, the metric includes issuances by all banks incorporated in a given country as well as their domestic and foreign affiliates ${ }^{8}$. This new indicator is one of the main contributions of this paper.

Our new aggregate shows that the international issuance of debt by banking groups in the post-crisis period has been larger than any of two alternative metrics -i.e., the BIS residence and nationality measures-. This regional pattern was also present in Brazil and Mexico, the two largest countries in the region in terms of output. Moreover, while, due to developments in international capital markets, issuances declined somewhat in 2013, they have stood in 2014 in spite of financial turmoil.

What are the potential financial system vulnerabilities in Latin America from these developments? After assessing whether activity in international debt markets differs between domestic and foreign banking groups, the paper explores whether increases in international indebtedness have been accompanied by increased reliance on wholesale funding. We also discuss additional sources of vulnerabilities derived from banks rollover risks in 2015 and beyond. Finally, we gauge central banks' readiness to provide liquidity in the event of a reversal in investors' sentiments towards Latin American debt.

The rest of the paper is organized as follows. Section II uses BIS data to characterize international funding patterns in Latin America during the pre- and post-global crisis periods. Section III presents a new aggregate for Latin American banks' international debt issuance that could prove useful for local supervisors in their surveillance of banks' international activities. This section also uses the new metric to discuss some stylized facts. Section IV assesses the potential sources of financial sector vulnerability in Latin America's banking systems associated with the new trends in banks' external funding patterns. Section $\mathrm{V}$ concludes.

8. More precisely, the metric includes issuances by domestic and foreign affiliates that are guaranteed by the banks incorporated in a given country. 


\section{A first glance at the Stylized Facts: External Financing by Banks and Non- Banks in Latin America}

The discussion in this section uses BIS data to understand the behavior of net external financing by banks and non-banks entities (through loans and debt securities) in Latin America. In most of this section, debt securities issuances are measured on a nationality basis; that is, for a given country the nationality definition includes international debt issuance by that country's domestic entities and their offshore affiliates. The increasing globalization of Latin American banks and corporations makes it relevant to analyze the recent behavior of these inflows at the consolidated level of the firm; i.e. on a nationality basis. ${ }^{9}$

In this definition, debt securities issuances by foreign entities operating locally are not included. At the end of the section, we incorporate in the discussion a second BIS measurement for international debt issuances: on a residence basis. This includes international debt securities issuance by all entities (domestic and foreign) operating in a given country. In this definition, however, offshore affiliates of domestic entities are not included.

Since financing through equity is not included, the measure of net external financing in this section is an indicator of domestic entities' change in external indebtedness. Moreover, since the definition only considers changes in the outstanding value of international liabilities (net inflows), we are not dealing with the capital account definition of the balance of payment which subtracts net outflows from net inflows. ${ }^{1011}$

The Latin American countries considered in this paper are: Brazil, Colombia, Chile, Peru and Mexico. These five countries share the characteristic of being highly integrated to the international capital markets, in the sense that they impose little restrictions to the movement of cross-border capital and have an important presence of foreign banks. ${ }^{12}$

Chart 2 shows the evolution of net external financing in Latin America from the mid1990s to the third quarter of 2014 on a nationality basis, both in US dollars and as a ratio of GDP. Although in US dollars, the value of net external financing in the post-global crisis period is larger than in any other previous episodes (Chart 2.b), measured in GDP terms, there are not significant changes in net external financing in Latin America between the pre-crisis (2007) and post-global crisis (2010) years, and the most recent ratios have even declined relative to the mid-1990s (Chart 2.a). As shown in Annex I, a sample of other Emerging Economies have displayed a similar pattern. ${ }^{13}$

9. For financial institutions, the term on a consolidated basis refers to entities conducting financial activities in only one financial sector (banking, securities or insurance sectors). Entities conducting financial activities in two or more regulated financial sectors are identified by the BIS (2012) as financial conglomerates. An alternative metric to the BIS aggregate that includes banks and its non-bank affiliates will be discussed in section III.

10. Also, balance of payments statistics considers data on a residence basis.

11. The term net external financing refers to net change in loans and debt securities liabilities. That is, new borrowing minus amortizations as well as debt issuances minus redemptions. The concept does not include asset-side transactions, such as lending abroad and purchases of international debt securities.

12. Brazil imposes some form of capital controls, but these are much less restrictive than in other emerging market economies, especially some Asian countries.

13. The countries included in the sample of other Emerging Economies are: India, Indonesia, South Korea, Malaysia, Philippines, Qatar, Russia, Thailand, and Turkey. There were two criteria for including countries: (a) that entities in the selected countries issued debt securities in the international capital markets and (b) that there were data available on these issuances. 
CHART 2. NET EXTERNAL FINANCING. LATIN AMERICA

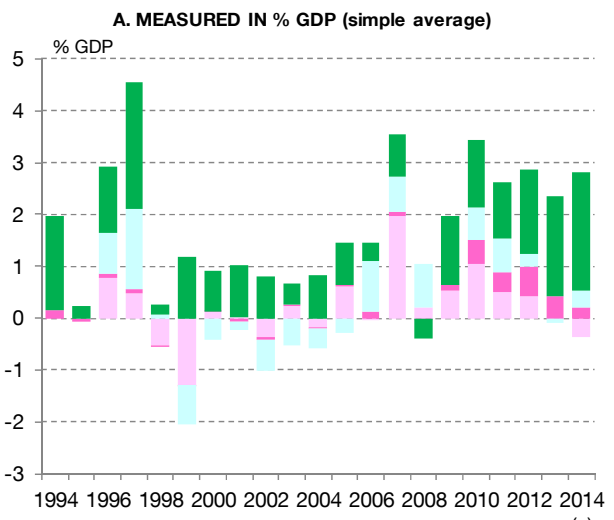

Loans on banks

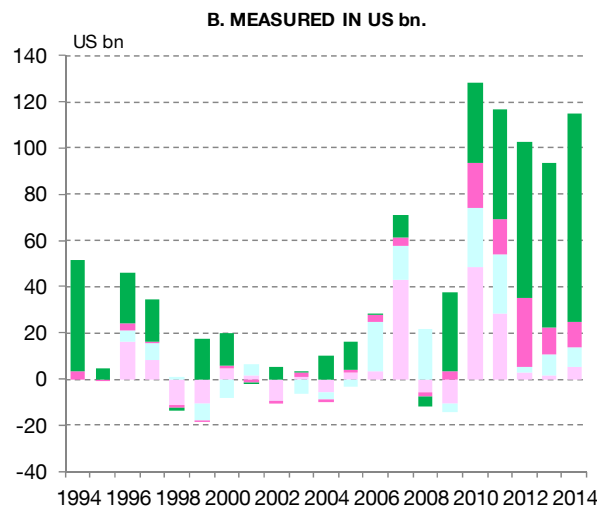

(a)

-Debt Securities Issued by Banks $₫$ Debt Securities Issued by Non-Banks Source: BIS international debt securities statistics, by nationality: BIS International Banking Statistics. (a)Annualized. Information available only up to the third quarter.

The chart also reveals that, with a few exceptions (2006-08), relative to GDP, issuance of debt securities by non-banks in Latin America has remained the most important source of external financing in the 1990s and 2000s. Moreover, while, as argued by Shin (2013) and Turner (2014), debt securities financing increased its relative importance in total net external financing at the expense of loan financing in 2012-14, shifts in the relative importance of external sources of funding are not strange to Latin America. For example, bank lending took center stage before 1998. In early 2000s, debt securities financing was again the primary source of external finance, a trend that reversed once more in 2006-2008, when bank loans dominated as the primary source of external finance. These developments are largely similar in other Emerging Economies, although less pronounced than in Latin America (see Annex I). ${ }^{14}$

\section{CHART 3. INTERNATIONAL DEBT SECURITIES ISSUANCES BY NACIONALITY, LATIN} AMERICA AS \% GDP (SIMPLE AVERAGE)

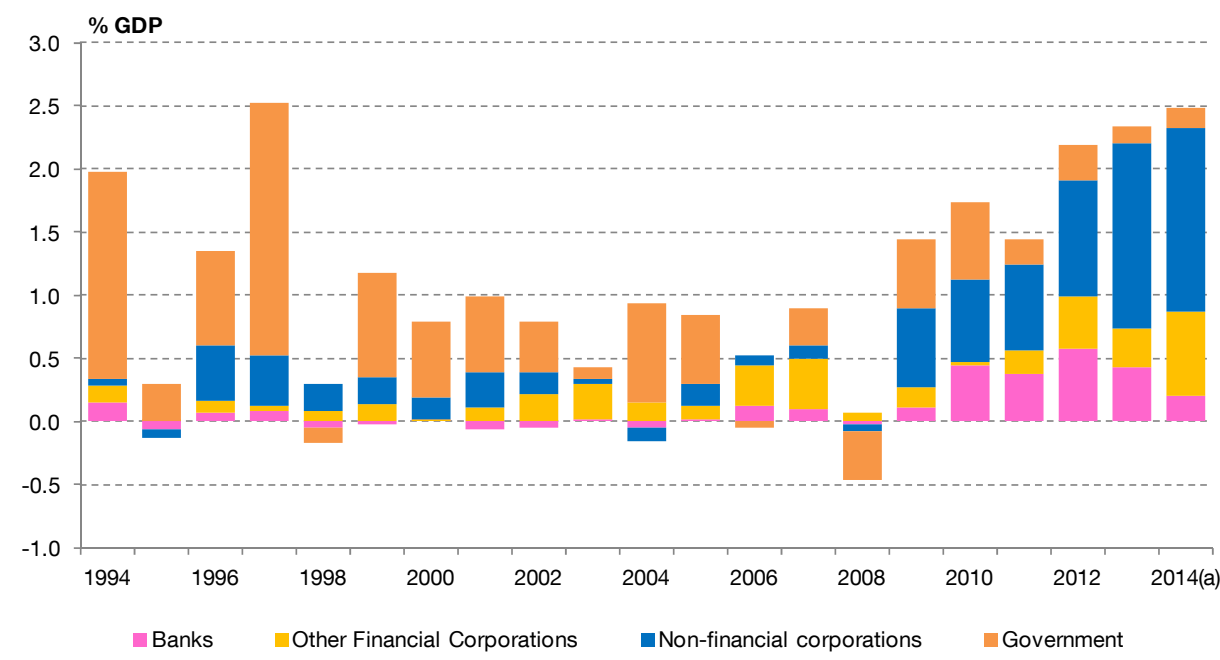

Source: BIS international debt securities statistics, by nationality. WEO (a) Annualized. Information available up to the third quarter.

Thus, if the post-global crisis ratios of external financing to GDP are not a novelty in the region and issuance of debt securities by non-banks remains the most important source of funding, what is new in Latin America? There are two major novelties and they

14 The periods where, relative to GDP, issuance of international debt securities by non-banks was not the principal source of external financing in other Emerging Economies were: 1996, 2005, 2006-2007, 2010 and 2013. 
are depicted in Chart 3. The first is that, in contrast to the 1990s and first half of 2000s, the private sector rather than the government has become the main issuer of international debt securities. Lower governments' indebtedness ratios reflect improved management of the fiscal accounts in the region. ${ }^{15}$

The second new development in Latin America is that banks have burst onto the international capital markets in the post-global crisis period; a novel development in the region. The suddenness of the large issuance of debt securities by banks indicates that this change does not respond to a process of greater depth and development of the region's banking systems. In contrast to Latin America, banks in other Emerging Economies have been important players in international debt markets since the 1990s and have become the most important issuers of international debt securities in the post-crisis period. ${ }^{16}$ (See Annex I).

In a nutshell, when analyzing external financing, the most important new trend in Latin America is that international debt issuances by banks has joined the already established (since the mid-2000s) issuance of debt securities by private sector non-banks as the major mechanism of external financing.

So far, we have focused only on the nationality measurement of debt issuances. However, from the perspective of Latin American banks' regulators who are concerned about changes in external indebtedness of the entire banking system, total banks' international debt securities issuances are underestimated using the nationality metric showed in the graphs above, since debt issuances by foreign banks operating in the region are not included. Alternatively, we could use the BIS data of debt issuances on a residence basis, which, as explained above includes international securities issuances by all entities (domestic and foreign) incorporated in a given country; but this measure excludes securities issued by foreign affiliates with explicit support from resident banks. Thus, usage of aggregate data (at the country level) has its limitations for the analysis of Latin American banking systems. ${ }^{17}$

Chart 4 shows that, in contrast to most other countries in the world, issuances by residence surpass issuances by nationality in a number of Latin American countries. ${ }^{18}$ This is consistent with the large presence of foreign banks in the region (affiliates of international banks incorporated in the region) which are also active in international capital markets. It is, therefore, not surprising that, according to BIS metrics, issuance by residence exceeds

15. This is also the case in other Emerging Economies, as shown in Annex I. However, the high interconnections between corporations and the public sector in a number of Asian countries, especially in the period before the Asian crisis (the so-called crony-capitalism), drastically underestimates the participation of the latter (as liabilities' final holders) in the 1990s. The Economist (2014) Crony-Capitalism Index ranks Malaysia and India among the top countries where politically-connected businesses are most likely to succeed.

16. Leaving aside the high interconnection between governments and corporations (including banks) in a number of Asian countries, the active participation of some Asian banks in international capital markets since the 1990s may also be reflecting a greater depth and development of these banks relative to their Latin American counterparts.

17. An additional issue is that the BIS Debt Securities Statistics classify debt securities according to the sector of the first issuer. For example, in Brazil "other financial corporations" include debt issues by Petrobras (a quasi-public oil company), if this company taps markets through its financial vehicles. Likewise, in these statistics debt issuances by the non-bank financial affiliates of banks are also classified as "other financial corporations". In our new proposed indicator international debt issuances by locally-supervised institutions we gather securities of banking groups, taking care of this issue (see section III).

18. Leaving aside offshore centers or key financial locations, in most countries in the world issuances by nationality are larger than issuances by residence. This is because domestic banks dominate the banking system and issuances by nationality include issuances which domestic banks carry out through their affiliates incorporated overseas -a substantial part of their deals is structured in such way-. While Latin-American banks are not atypical, in this sense, the presence of affiliates of foreign banks who are tapping international capital markets is substantial. 
issuance by nationality in Chile, Mexico and Peru, the three countries in our sample with a very large presence of internationally-active foreign banks. ${ }^{19}$

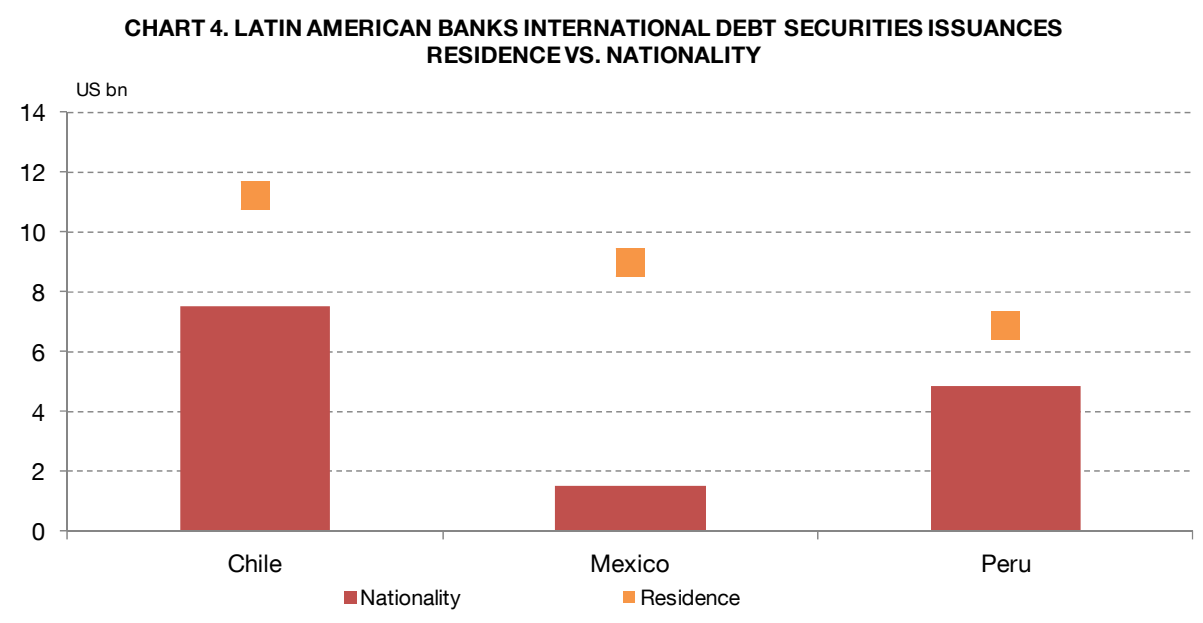

Note: cumulated net debt issuances 2010-2014 (3Q)

A key issue is that, in Latin America, foreign-banks are mostly incorporated as fully independent institutions, and accordingly subject to local surveillance. Neither of the two BIS measures includes all types of debt securities issuances by banks supervised locally. For instance, none of these two measures includes the issuances of foreign banks in Latin America through financial vehicles incorporated in offshore centers. Moreover, banks' issuances through financial non-bank affiliates, such as special-purpose vehicles, are not included (they would be classified as non-bank financials). A comprehensive account of debt issuances requires data at the micro level; that is, it is necessary to collect information based on individual debt securities. We do that in the next section.

Should the rapid increase in the issuance of international securities by banks be a concern ${ }^{20}$ And does it matter whether most of the issuances are undertaken by the domestic banks or by their offshore affiliates or by foreign banks operating locally? In other words, what are the risks for the stability of Latin America's financial systems arising from recent developments? As a first step to answer these questions, in the next section we construct a new aggregate of banks' international debt issuances that encompass all institutions supervised by the local authority.

19. This is not the case in Brazil and, as a result, the dollar value of issuances by nationality is greater than the corresponding value of issuances by residence for the region as a whole (as represented by the five countries in our sample). Ideally, we would also need to compile data on debt securities issuance by banks' clients. That exercise, however, is beyond the scope of this paper and material for future research.

20. Ideally, we would also need to compile data on debt securities issuance by banks' clients. That exercise, however, is beyond the scope of this paper and material for future research. 


\section{A New Metric of Banks' International Debt Issuances}

As discussed above, an aggregate that adequately reflects the exposure of local banking systems to international debt markets needs to include all entities that fall under the supervisory purview of the local authority. This is especially important in a number of Latin American countries, where the participation of foreign banks is very large and these banks are established as independent, fully-capitalized entities. After all, in case of financial difficulties of a foreign affiliate operating in Latin America, its parent bank is not liable for the affiliate's debt. The parent's bank legal exposure is limited to capital and intragroup funding. ${ }^{21}{ }^{22}$ If the affiliate's capital is insufficient to cover its debt liabilities, the responsibility on how to deal with the insolvency/liquidity problem lies on the Latin American country's supervisor. This, of course, does not necessarily imply that parent banks and their supervisors would disregard the emergence of financial problems in their affiliates. Beyond legal issues, a parent bank faces a reputational challenge in case of difficulties in one or more of its affiliates, especially if it has a large franchise that extends to several countries in the region. ${ }^{23}$ Foreign banks' supervisors can also play a role through two mechanisms: (a) the mandate of surveillance of the foreign affiliates of their local banks under the requirement of consolidated supervision and (b) the signing of letters of agreement of collaboration between home- and host-country supervisors.

This section introduces a new metric that we call: International Debt Issuances by Locally-Supervised Institutions. This indicator includes the international debt issued by domestic banking groups and foreign-owned banking groups. The former comprises all domestic banks (banks whose controlling parent institution is located in the country under analysis), their domestic bank and non-bank affiliates, and their supported foreign offices. The latter comprises all foreign-owned banks incorporated in a given country (with a controlling parent institution incorporated outside the country), and their supported foreign offices. Foreign banks are included only if they are fully independent entities. Annex II provides further detail on methodological issues.

Our metric has several features which differentiates it from existing ones. First, we are restricting the analysis to these entities whose legal risks lie in a Latin American country. ${ }^{24}$ In other words, we are not focusing on all resident banks, but only on locally-supervised Latin American banking groups. ${ }^{25}$ Thus, we are not including foreign banks' issuances when these entities are supported by their parent banks. Second, we are including the issuances of foreign affiliates of (fully-independent) foreign banks (i.e., Santander Brazil SA-Cayman Island). ${ }^{26}$

\footnotetext{
21. See, Cerutti et al (2011) and Cerutti (2013)

22. For example, Santander SA is not liable for the international debt of Santander Brazil SA (and debt issued by the Brazilian bank, such as Santander Brazil SA-Cayman Island).

23. This is the case of Spaniard banks operating in Latin America.

24. Hence our metric classifies deals according to the country of ultimate risk. A similar metric applied to non-financial companies is developed in Fuertes and Serena (2014).

25. Resident banking groups need not be locally supervised institutions. This is an important distinction, from a conceptual point of view. Some regions, such as Emerging Asia, or Western Europe, host a large number of foreign branches, which are not under the purview of local supervisors. (see Fiechter et al. (2011)). From an empirical point of view, the largest foreign banking groups in Latin-America are locally-supervised institutions.

26. These two features make our criteria different from the one used by the IDB (2014), which focuses on debt by all resident institutions, and nationals non-residents. Unlike the IDB paper, as mentioned above, our metric explicitly excludes information on foreign resident banks if they have support from their parent companies. Moreover, we are gathering the debt issuances of resident institutions at the consolidated level; hence, if (fully-independent) foreign banks use foreign affiliates to carry out deals we include them.
} 
An additional distinctive feature is that we classify securities issuances according to the sector of the parent entity. Hence, if a deal is carried out by a financial non-bank affiliate supported by a bank, we classify the issuance as a bank-deal (the same applies to nonfinancial affiliates of banks). This is consistent with BCBS requirements on banking supervision, which encourages monitoring entities at a consolidated level.

Using the example of two banks operating in Brazil (Itaú and Santander), Table 1 illustrates the differences in country classification of international debt issuances between our metric and the traditional BIS aggregates: by nationality and by residence.

Table 1. A comparison between alternative classifications of international debt issuances

\begin{tabular}{|c|c|c|c|c|}
\hline & \multicolumn{2}{|c|}{ Domestic banking group } & \multicolumn{2}{|c|}{ Foreign-owned banking group } \\
\hline & $\begin{array}{c}\text { Domestic bank } \\
\text { [Itaú Brazil] }\end{array}$ & $\begin{array}{c}\text { Foreign-office } \\
\text { [Itaú Brazil (Cayman } \\
\text { Islands)] }\end{array}$ & $\begin{array}{c}\text { Foreign-owned bank } \\
\text { [Santander Brazil } \\
\text { SA] }\end{array}$ & $\begin{array}{c}\text { Foreign-office } \\
\text { [Santander Brazil SA } \\
\text { (Cayman Islands)] }\end{array}$ \\
\hline By nationality & Brazil & Brazil & Spain & Spain \\
\hline By residence & Brazil & Cayman Islands & Brazil & Cayman Islands \\
\hline $\begin{array}{l}\text { Locally-supervised } \\
\text { institutions }\end{array}$ & Brazil & Brazil & Brazil & Brazil \\
\hline
\end{tabular}

Since Bank Itaú Brazil and its foreign office, Itaú Brazil-Cayman Islands, fall under the purview of the Brazilian supervisory authority, international debt issuances by both institutions are included as Brazilian in our metric: by locally-supervised institutions. These issuances are classified similarly in the BIS metric by nationality; however, the BIS measurement by residence classifies the international debt issuance by the Cayman Islands office of Bank Itaú as liabilities of the Cayman Islands. Likewise, since Bank Santander Brazil SA and its foreign office, Santander Brazil-Cayman Islands, are supervised by the Brazilian authorities, the international debt issuances of both entities are included as Brazilian in the metric: by locally-supervised institutions. However, the BIS aggregate by residence classifies the international debt issuances by Santander Brazil-Cayman Islands as liabilities of the Cayman Islands; and in the BIS aggregate by nationality all international debt issuances by Bank Santander Brazil are classified as Spaniard. This example shows the importance for Latin American supervisors of a metric that captures all banks' activities in international debt markets. The large participation of foreign-owned banking groups and the use of foreign offices by domestic and foreign-owned groups to tap the international capital markets warrant such an aggregate.

We use deal-level data, compiled by Bloomberg, to construct and compare the three alternative metrics for our sample of Latin American countries. As a first step, we show gross issuances. Also, it should be noted that we are obtaining information on banking groups which, as mentioned above, would include all non-bank affiliates of the "parent issuer". 
Chart 5 presents the comparison between the three alternative metrics for LatinAmerica. In Latin America, foreign-banks are locally supervised. Hence, by construction debt securities issuances of locally-supervised institutions are at least equal than the larger of the two alternative metrics -by residence, or by nationality-. ${ }^{27}$

\section{CHART 5. LATIN AMERICAN BANKS GROSS INTERNATIONAL DEBT SECURITIES ISSUANCES ALTERNATIVE METRICS}

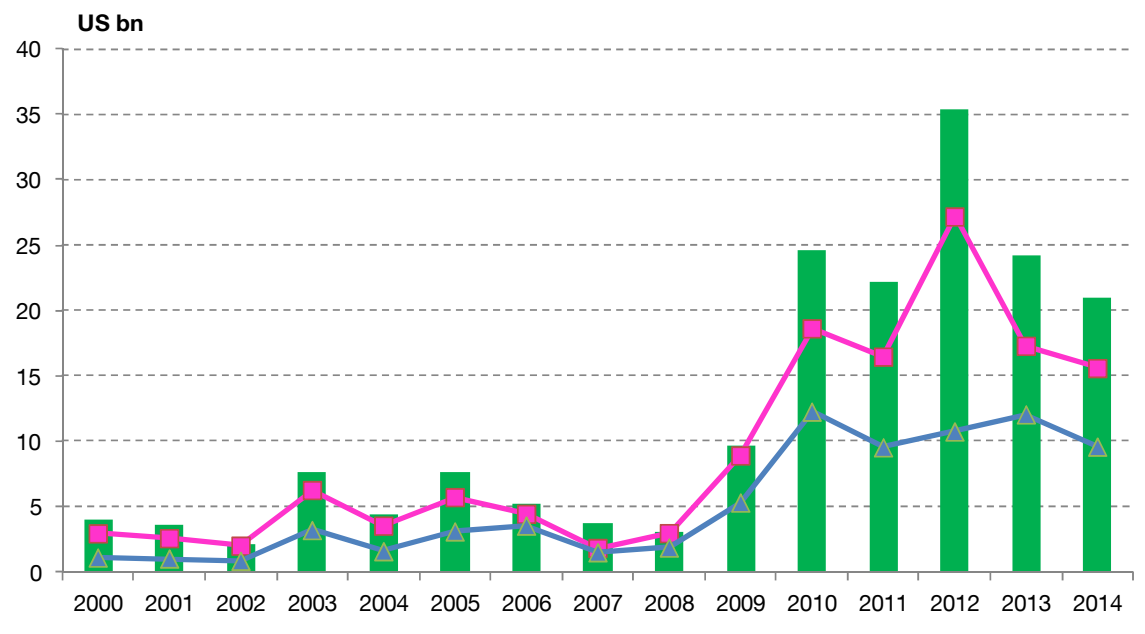

Locally supervised institutions $\quad \rightarrow$ By Nationality $\quad-$ By Residence

Source: Bloomberg, own elaboration.

There are two findings. The first is that the new aggregate strongly reinforces the observation in Section II that Latin American banks (banking groups in chart 5) increased significantly their (US dollar value of) international debt issuances in the period after the global financial crisis. This is also the case for other Emerging Economies (see Annex III).

The difference between our new metric and the BIS metric by nationality is smaller in other Emerging Economies than in Latin America, reflecting the lesser importance of foreign banking groups in the former. In Latin America, issuances of foreign banking groups added $30 \%$ to issuances by nationality; this compares with $20 \%$ in other Emerging Economies. As chart 6 shows, the heightened activity of foreign banking groups in Latin America is concentrated in the post-crisis years.

The second finding is that issuances in Latin America and other Emerging Economies have slowed down somewhat since 2013, although they remain substantially larger than in the pre-crisis period.

The last finding is consistent with developments in international capital markets that affected the entire emerging markets class. In May, 2013, the US Fed announced the beginning of the end of its purchase program of large quantities of government paper and other long-dated securities (known as QE--Quantitative Easing). The announcement of the tapering of QE, brought about a sharp increase in investors' risk aversion, as the

27. In Latin-America, there are very few institutions which are not under the purview of the local supervisors. After 2010 , debt-issuances by these institutions have amounted only to 0.6 US billion; since 2010, we have recorded a sole debtissuance of negligible amount. A similar downward trend in debt-issuances by non-supervised entities is perceived in the group of other emerging economies: the trend towards local supervision of foreign affiliates is general. Foreign affiliates of Chinese banks in Emerging Asia seem an exception, but their issuances of debt-securities are not large relative to the funding obtained by foreign offices of locally-supervised institutions; hence, debt-issuances by locally-supervised institutions remain larger than the other two measures. 
announcement was taken as a signal that the Fed would soon increase its policy interest rate. As a result, purchases of risky instruments, including emerging market securities declined significantly. Following the Fed's announcements that its criteria for increasing interest rates were far from being met (unemployment rates below 6\%), investors renewed their large demand for emerging markets' debt instruments, including from Latin America. This episode strongly indicates the potential vulnerability of Latin American debt financing to the eventual increase in US interest rates. The next section explores whether banking systems with the largest reliance on international debt securities issuance to meet their financing needs are the most vulnerable to an external shock.

\section{CHART 6. LATIN AMERICAN BANKS GROSS INTERNATIONAL DEBT SECURITIES ISSUANCES. DOMESTIC AND FOREIGN BANKING GROUPS}

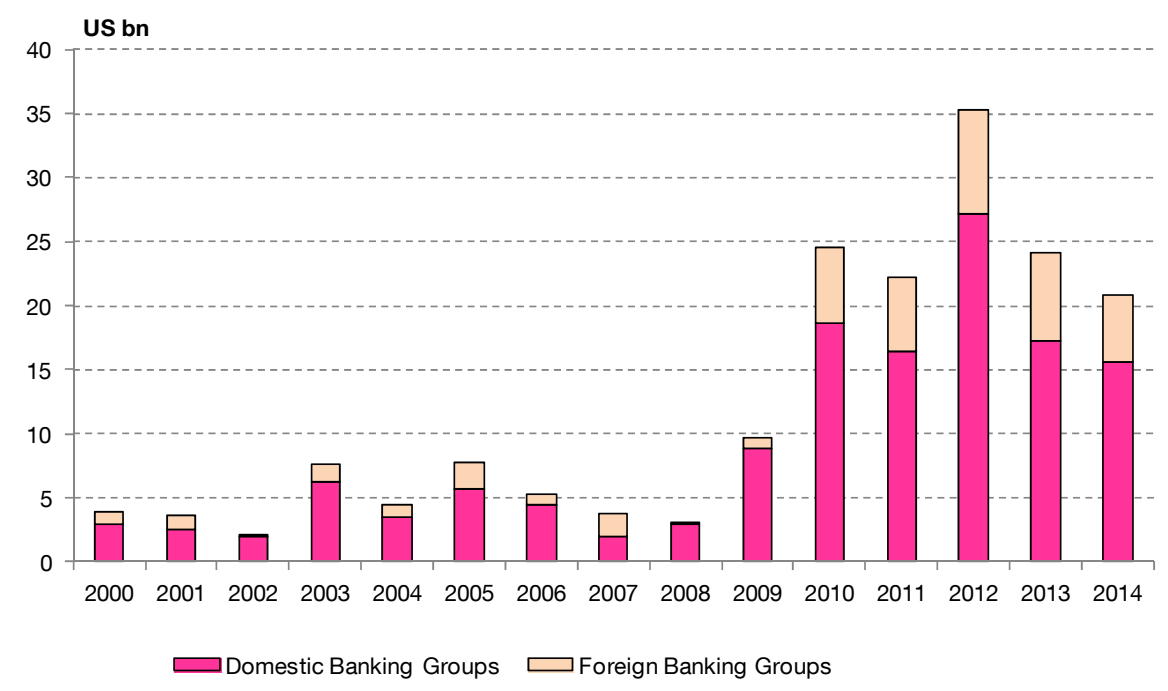

Source: Bloomberg, own elaboration

Annex IV shows the behavior of individual countries according to the classification of international issuance of debt by locally-supervised institutions. The data shows that, with some diversity, countries follow a similar pattern. In all countries in the sample, gross international debt issuances increased rapidly from 2010 to 2012. While they have slowed down somewhat in 2013-14, they remain at much higher levels than in the pre-crisis period. The only marked difference is that Colombian banks have not tapped international markets in 2014. Chart IV.2 in Annex IV depicts international debt issuances relative to GDP, showing that the trend is general. This suggests it does not depend on country-specific developments; though there are differences in the size of the increase: Chile ranks as the country where debt-securities issuances in the period 2010-2014 are largest relative to GDP, followed by Peru, Brazil, and Colombia; Mexico is the country where debt-securities issuances are smallest. ${ }^{28}$ The Annex also highlights the relevance of our new metric to monitor external wholesale funding for banking supervisory purposes. As mentioned before, in Latin America debt securities issuances of locally-supervised institutions are at least equal than the larger of the two alternative metrics. In some countries (Mexico for example), external debt issuances by nationality are, generally, much further away from our measure than issuances by residence. This reflects the large presence of foreign-owned banking groups who have

28. Annex III (Chart III.8) shows similar results for the group of other emerging market economies. With the exception of Korea, the ratio of banks' international debt issues to GDP increased significantly during the period 2010-14 (relative to the period 2000-09). Turkey stands out for the large increase in this ratio (by both domestic and foreign banks). 
been active in the international capital markets. In other countries (Brazil and Chile in our sample) it is the metric by residence the one falling short of our measure. This reflects that domestic banking groups have been using their foreign offices to tap international markets. But the main message is that, in Latin America, none of the two standard metrics can be used as a short-cut.

Accordingly, we now turn to the analysis of the risks to Latin American financial systems posed by the observed recent trends, using the metric by locallysupervised institutions. 


\section{$4 \quad$ Are there new Financial Vulnerabilities in Latin America's Banking Systems?}

The recent literature has highlighted some potential risks derived from the increased issuance of private sector debt in the international capital markets. Specifically, the larger concern is that the markets for international debt, in general, and those for emerging economies' debt in particular, will be severely affected by the increase in the Fed's interest rate and the ensuing reduction in international liquidity. ${ }^{29}$ This might have important adverse consequences on the local banking systems of Latin America if sources of funding are curtailed (directly and/or indirectly). In turn, the importance of these effects depends, inter alia, on banks' relative dependence on wholesale vs. retail funding, banks' refinancing needs, and the banking system's capacity to respond to external shocks. In this section, we analyze these features to assess potential vulnerabilities of Latin America's banking systems. As a starting point, we establish whether there is a differentiated behavior in international debt issuances between domestic and foreign banking groups.

\subsection{Do Foreign Banking Groups behave differently than Domestic Banking Groups?}

The large participation of foreign banks in Latin America is well documented. In some countries, foreign-owned banks operating in the region account for over a third of assets of the total banking system (72 percent in Mexico, 37 percent in Peru and 33 percent in Chile). Chart 7 shows the annual rate of growth of bank credit to the private sector for the combined Latin American countries in our sample. While cross-border lending from global banks to Latin America contracted sharply during the crisis, and did not resume in the post-crisis years, this has not been the case for foreign banks operating in the region. On an overall basis, the local lending of foreign-owned banks has been similar to that of domestic banks in the post global crisis period.

CHART 7. LATIN AMERICA, BANKING CREDIT TO THE PRIVATE SECTOR

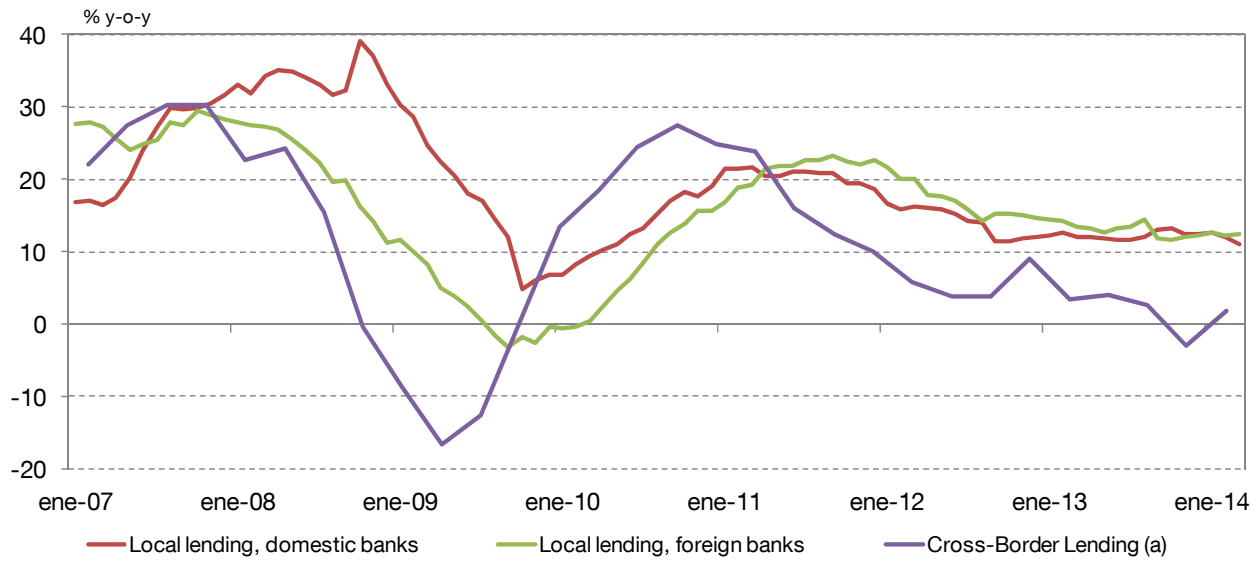

Source: BIS International Banking Statistics, by residence; national sources, own elaboration (a) Cross-border lending to all sector (includes public sector)

29. See, for example IMF, 2014a. A particular concern raised by private sector participants is that, due to new banking regulations, the role of international banks as market-makers and holders of emerging markets debt has been sharply reduced. Thus, the effect of the eventual increase in US interest rates on debt markets could be significantly larger than in previous episodes. See, http://www.emergingmarkets.org/Article/3389503/Even-a-gentle-Fed-could-savage-EMbonds-as-banks-liquidity-vanishes.html? LS=EMS1083894. 
However, recent literature shows that foreign banks tend to amplify the adverse effects of external shocks on real credit growth in Latin America. Using bank-level data, Galindo, Izquierdo and Rojas-Suarez (2012) found that interest rates charged and loans supplied by foreign-owned banks responded more to external financial shocks than those supplied by domestically owned banks. This behavior is apparent in Chart 7 . During the global financial crisis, the contraction in real credit growth by foreign banks was significantly larger than domestic banks. ${ }^{30}$

How does the behavior of foreign banking groups differ from that of domestic banking groups in terms of issuance of international debt? Some analysts have argued that, because of their connections with their parent houses, it is possible that foreign banking groups find it easier than domestic (especially small) banks to obtain cheaper funding abroad.

Chart 8 shows the cumulated issuance of external debt in the period 2010-2014 for domestic and foreign banking groups (relative to the assets of the corresponding group in 2013) in Latin America. At the regional level, domestic and foreign banking groups displayed similar ratios of international debt securities issuances to assets. Both groups, moreover, displayed a similar division of issuance activities between the resident banks and their foreign offices (approximately 40\% and 60\% respectively). ${ }^{31}$

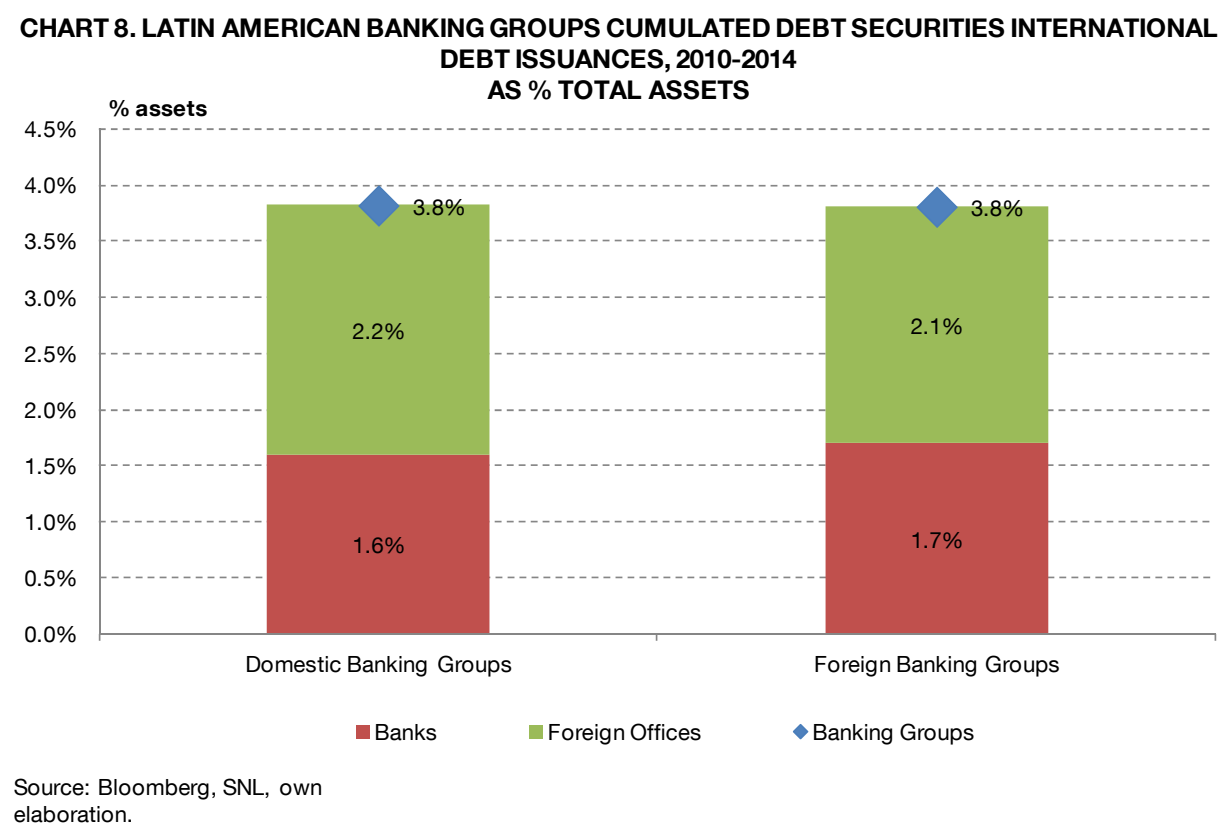

Notwithstanding similarities at the regional level, there are marked differences between Latin American countries (see Annex V). ${ }^{32}$ In particular, Brazil and Chile were the countries with (relative) less difference in the ratios of cumulated debt issuance to assets between domestic and foreign banking groups. In Colombia, the entire activity can be attributable to domestic banking groups while activity by foreign banking groups dominated in Mexico and Peru. Likewise, foreign offices accounted for most of the debt issuance activity of foreign banking groups in Mexico and for most of the issuance of

30. This did not hold for all foreign banks, however. It has been argued that Spaniard banks incorporated in Latin America behaved more like domestic banks during the crisis in terms of credit supply (Galindo et. al. 2012).

31. These features contrast with those in other Emerging Economies where foreign banking groups showed a larger ratio of international debt securities issuances to assets than domestic banks and most of foreign banking groups' activity was conducted through their resident banks (see Annex III).

32. There is also considerable heterogeneity among the countries in the group of other Emerging Economies. 
international debt by domestic and foreign banking groups in Brazil. Foreign offices did not play a role in the issuance of external debt by foreign banking groups in Chile, or by domestic banking groups in Colombia.

While informative, the data in Chart 8 and Annex $V$ are not sufficient to raise supervisors' concerns about potential fragilities in either their domestic or foreign banking groups or in both. Additional information regarding banks' changes in funding patterns is needed. In the next sub-section we deal with that issue by examining whether banks' overall reliance on wholesale funding has increased in recent years.

\subsection{Changes in Banks reliance on Wholesale Funding}

The global financial crisis showed that banking systems that heavily depended on wholesale funding were more vulnerable to the effects of the international shock than banking systems that mostly relied on domestic deposits to finance their overall activities. As has been established in the literature, domestic deposits (and some other long-term domestic liabilities) tend to be a more stable source of bank funding than international liabilities. This finding has motivated the recent recommendations by the Basel Committee on Banking Supervision on liquidity ratios. ${ }^{33}$

As indicated by Guidotti and Rojas-Suarez (2011), the high ratios of bank deposits to credit were an important reason behind the strength of Latin American banking systems during the crisis. ${ }^{34}$ Has the increased issuance of international debt by Latin American banking groups been accompanied by an increased dependence on wholesale funding? In other words, have the recent shifts in trend in international funding resulted in increased vulnerabilities of Latin American banking groups? And, what can be said about relative strengths/fragilities between domestic and foreign banking groups?

Chart 9 shows the composition of banks' liabilities from 2010 to 2014 for the region as a whole and for the five countries in our sample. Each panel presents the breakdown of liabilities, decomposed into three categories: (a) wholesale funding (excluding international debt); (b) international debt; and (c) core liabilities -total liabilities, excluding wholesale funding-. Data for total liabilities, wholesale funding and core liabilities are obtained, at bank-level data, from SNL (see Annex II for more details on the methodology). ${ }^{35} \mathrm{SNL}$, however, does not produce separate information on the stock of international debt issued by banks. We construct the latter series using our information on gross securities issuances and redemptions, obtained from Bloomberg. It includes corporate bonds, medium term bonds, and private placements -the only caveat is that we are probably missing very short-term funding in international markets. Since our data starts in 2000 and maturities were not long in the 1990s, we expect to have an accurate estimation of the outstanding stock of external debt securities.

33. Specifically, the net stable funding ratio attaches greater weight (more stable) to liabilities with longer maturities (effective residual maturities greater than a year) and to deposits than to wholesale funding. See, Basel Committee on Banking Supervision (2014)

34. On average, Asia and Latin America displayed high ratios of bank deposits to credit and low ratios of short-term international liabilities to credit. This contrasted with Emerging Europe, which on average had a lower reliance on bank deposits and a higher dependence on the more volatile short-term international loans to fund credit.

35. See http://www.snl.com/. SNL defines total liabilities as the sum of total financial liabilities, and non-financial liabilities. We focus on total financial liabilities, and break them down between Core Liabilities, Wholesale Funding (excluding external debt), and external wholesale debt. In Chart 9, Wholesale Funding (excluding external debt) includes Total debt, Interbank Deposits, and other non-core financial liabilities. Also in chart 9, Core Liabilities are defined as Total Deposits, minus Bank-Deposits. We describe the composition of each group in Annex II. 
There are three key results from Chart 9. First, the participation of the stock of international debt issued by Latin American banks in total banks' liabilities remained low in all countries. Banking groups in Peru displayed the highest ratio among countries, but that ratio was only 9 percent in 2014 (up from 4.6 percent in 2010). Second, notwithstanding low ratios of banks' outstanding external debt to liabilities, the continuous and rapid increase of these ratios in the period 2010-14 is noticeable, and it could be a potential source of financial vulnerability. ${ }^{36}$

\section{CHART 9. BANKS' LIABILITY STRUCTURE. LOCALLY-SUPERVISED INSTITUTIONS}

LATIN-AMERICA 5

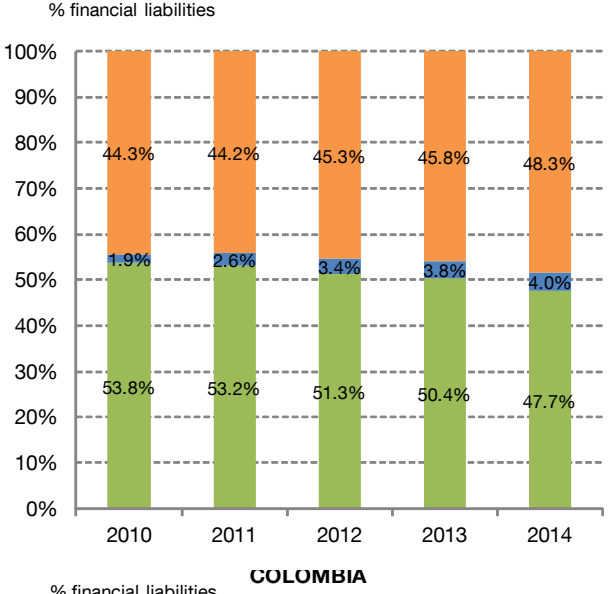

$\%$ financial liabilities

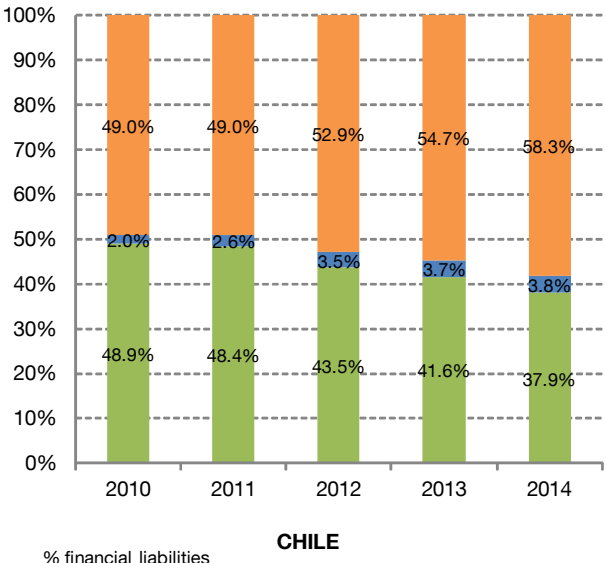

$\%$ financial liabilities $\quad$ CHILE

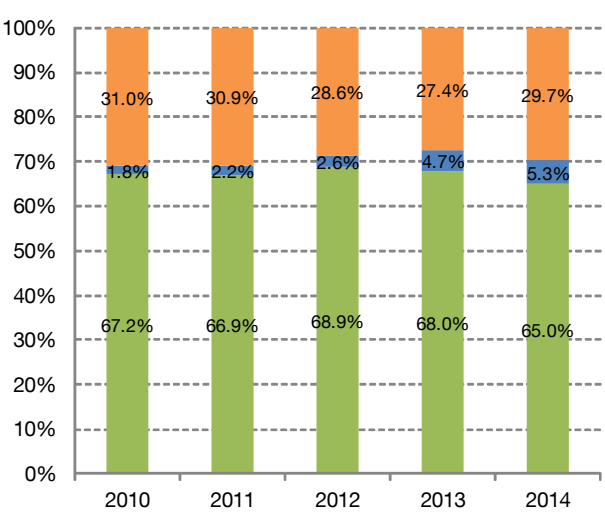

PERU

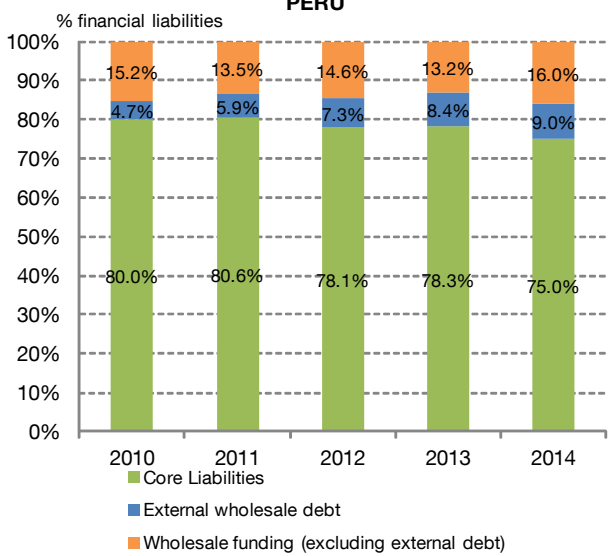

36. In comparison to other Emerging Economies, Latin America as a region has increased more its dependence on wholesale funding (see Annex III). 
In the context of the increasingly less favorable international financial environment facing Latin America at the time of this writing, roll-over of the outstanding stock of banks' external debt might take place at higher costs, posing a burden on banks' profitability. Banks' roll-over risks will be discussed further below.

Banks' capacity to roll-over maturing external debt also depends on their overall liability composition. Banks with a large ratio of wholesale funding to liabilities might find it harder to rollover maturing external debt (a component of wholesale funding) in a deteriorating international environment since these banks would be perceived as more vulnerable to adverse changes in economic/financial conditions. Moreover, due to the limited development of local capital markets (associated to extremely low savings ratios in Latin America), domestic wholesale funding would not be an effective substitute of external debt. Indeed, in the context of a decreased availability of external funding, the cost of domestic funding would most likely increase. This leads to the third and most important result from chart 9 and Annex VI, namely that banking systems' vulnerabilities, assessed by their reliance on wholesale funding differ significantly between countries. In Brazil, domestic and foreign banks have significantly increased their reliance on wholesale funding (the addition of wholesale funding excluding cumulative debt issuances and cumulative external debt issuances in chart 9). Annex VI shows that, by 2014 , the ratio of wholesale funding to total liabilities reached about 64 percent for domestic banking groups and 52 percent for foreign-owned banking groups (from 49 and 38 percent respectively in 2010). Although the reliance of Mexican banks on wholesale funding is relatively high (around 50 percent), the ratio of wholesale funding to total funding has remained quite stable during the period under study for both domestic and foreign banking groups. In Colombia and Peru, followed by Chile, banks largely finance their activities through domestic deposits; however, the proportion of wholesale funding has increased in Chilean and Peruvian banks.

Thus, the fast expansion of funding through external debt by banking groups (Chart 5, Annex IV) contributed to an increased reliance in wholesale funding in some countries but not in others. As mentioned above, Brazil and, to a lesser extent, Peru are examples of the former. In Brazil, banking groups (domestic and foreign) not only expanded their outstanding stock of external debt but also their stock of other forms of debt. In Peru, foreign banking groups, which held the largest ratio of external debt to total liabilities among Latin American countries in 2014, decreased their reliance on other forms of wholesale funding somewhat. As a result, although total wholesale funding as a proportion of liabilities increased in the period 2010-2014, the ratio remained below 30 percent. In Colombia, the increased issuance of external debt by domestic banks was accompanied by a similar decline in other forms of wholesale funding. Consequently, reliance on overall wholesale funding by Colombian banks did not increase in the period under consideration.

\subsection{Other Factors Affecting the Vulnerability of Latin American Banking Groups}

While the combination of increased issuance of international debt and the accompanying augmented reliance on wholesale funding by some Latin American banking groups signals an increase in their vulnerability to shocks in the international capital markets ${ }^{37}$ (especially a potential reduction in global liquidity derived from an increase in the Fed's interest rates), there are a number of additional factors that affect the resilience of the banking systems to shocks. In particular, it is important to stress that the solid capitalization buffers observed in the region, as well as significant improvement in banking supervision, are key sources of strength

37. As mentioned above, the suddenness of the large issuance of debt securities by banks indicates that this change did not respond to a process of greater depth and development of the region's banking systems. 
and resilience to external shocks, ${ }^{38}$ and the main reason why no Latin American banking system experienced severe difficulties during the global financial crisis.

Recognition of these sources of strength, however, does not preclude the identification of factors that might potentially increase banking system's financial vulnerability. Thus, in this sub-section we briefly discuss two of these factors ${ }^{39}$. The first deals with banks' rollover risk. The second relates to the central banks' capacity to respond to external shocks.

\subsubsection{BANKS' ROLLOVER RISKS}

The large issuances of international debt securities in the post global crisis period might create substantial refinancing needs for Latin American banks. A telltale indicator is the growing discrepancy between net and gross debt issuances, shown in chart $10 .{ }^{40}$ It is apparent how up to 2012, the substantial increase in gross issuances was accompanied by a similarly large increase in net issuances; therefore allowing for an increase in banks' lending capacity. Since 2013, however, a substantial part of gross issuances has covered the refinancing needs opened by debt issuances in the previous years. Although a similar pattern has been observed in other Emerging Economies, redemptions relative to gross issuances in 2013-14 have been smaller than in Latin America and, therefore, the relative decline in net issuance has been less pronounced in the former set of countries (see Annex III).

To assess whether rollover risks might be on the rise requires looking at the maturity of recent issuances, the redemption profile of outstanding debt, and investigating the holders of debt -and their potential investment strategies-. We proceed to perform this analysis, by looking first at maturities.

CHART 10 LATIN AMERICAN BANKS NET DEBT SECURITIES ISSUANCES AT INTERNATIONAL MARKETS

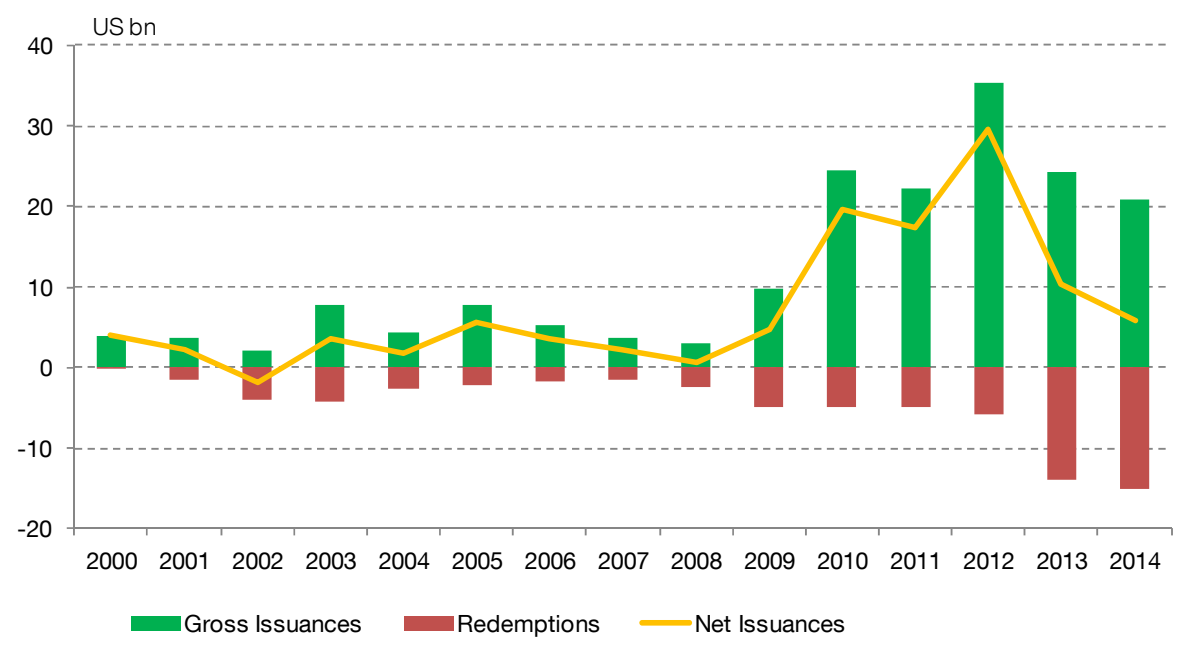

Source: Bloomberg, own elaboration.

38. See IMF (2014b)

39. An important issue not discussed here, due to lack of data, relates to currency mismatches. While regulatory constraints in Latin America prevent the emergence of large currency mismatches between banks' assets and liabilities, the potential of hidden currency mismatch has not been eliminated. The most straightforward example comes from the observation, discussed in Section II, that Latin American non-financial corporations have also been very active in the international bonds markets (see also, IMF, 2014b). Usually, these firms are large entities that also borrow from the local banks. If these non-financial corporations did not adequately hedge their currency exposures, a sharp depreciation of the local currency would decrease their capacity to service their external debt compromising also their capacity to make good on their liabilities with local banks.

40. The values of gross issuances reported in Chart 10 are equal to the values shown in Charts 5 and 6 under the metric: International Debt Issuances by Locally-Supervised Institutions. 
Chart 11 shows the weighted-average maturity of international issuances by Latin American domestic and foreign banking groups. A first and encouraging finding is that, on an overall basis, maturities have not been short in absolute terms; nonetheless, average maturity in recent years (2013-14) was lower than in the pre-crisis years (2005-07). The latest data available shows that in 2014, domestic banks were issuing debt at shorter tenors than foreign-owned banking groups. Most importantly, however, is that the sheer increase in debt securities issuances, also shown in the chart, implies that future refinancing needs might be substantially higher than in the past years.

\section{CHART 11 LATIN-AMERICA MATURITY OF ISSUANCES. BY TYPE OF BANK}

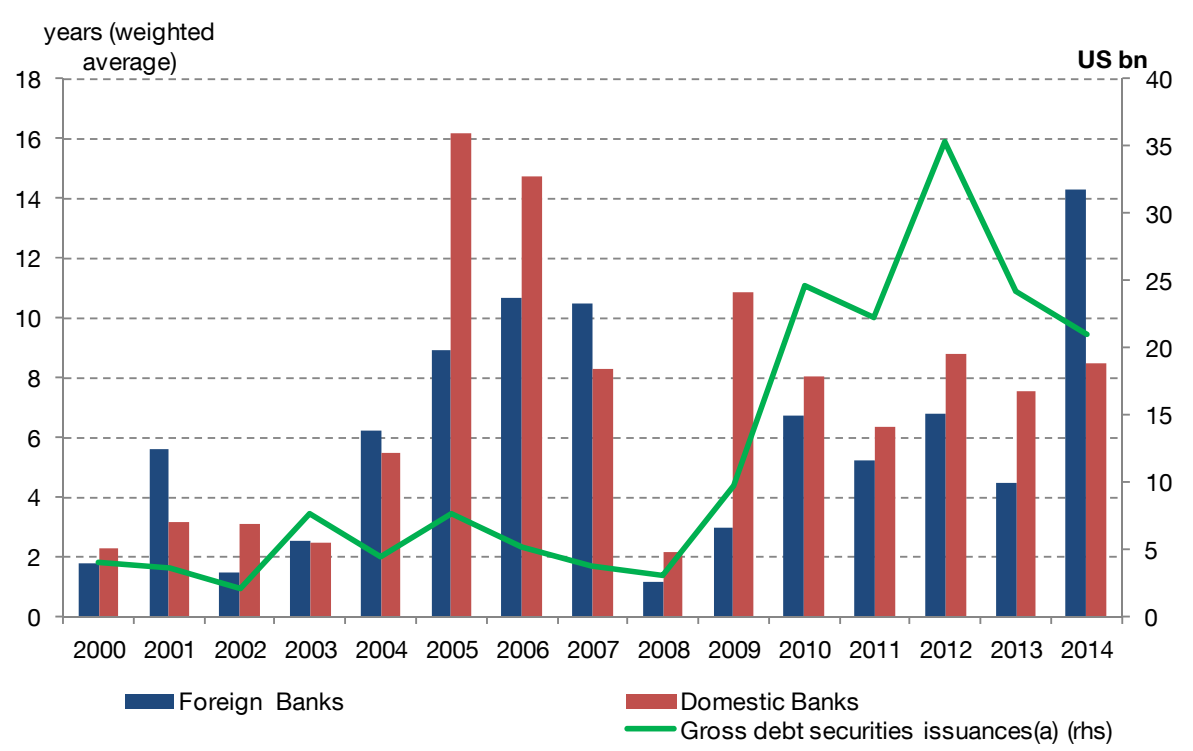

Source: Bloomberg, own elaboration.

(a) Locally-supervised institutions, intermational markets

Chart 12 shows the redemption profile of outstanding debt since the early 2000s. ${ }^{41}$ Maturing debt rocketed in 2013-14 -they were close to three times higher than in 2012. Even assuming banks net debt securities issuances do not increase in the next years (2015 and beyond), banks would need to tap international markets at a large scale if they want or need to rollover outstanding debt. As shown in the chart, redemptions in 2015-16 remain at high levels. The concentration of maturing debt in these years is worrisome in the context of high uncertainties in the international capital markets and the probable increase in the Fed's interest rate. As it is well known, if roll-over risks rise substantially, banks' alternative would be to cut lending or other activities, since it is probably difficult to substitute this influx of dollar funding. ${ }^{42}$

Annex VII presents a breakdown of banks' redemption profiles since 2010 by country. The information is provided for all locally-supervised institutions; as well as decomposed by domestic and foreign banking groups. Maturing debt securities in 2015 and 2016 represent close to $20 \%$ of the outstanding external debt securities in Brazil, Chile, and Colombia. In the first two countries outstanding debt relative to central banks' international reserves is also high, as we discuss below.

41. Redemptions are calculated using the maturity of debt securities issued since 2000 . Therefore, redemptions are probably underestimated in the first years of our sample period.

42. The maturity profile for the group of other Emerging Economies is worse than for Latin America: debt maturing in 2015 is 50\% higher than in 2014 and almost triples the value of 2013. Redemptions continue at high levels until 2019 (see Annex VII). 


\section{CHART 12 LATIN AMERICAN BANKS. INTERNATIONAL DEBT MATURITY PROFILE}

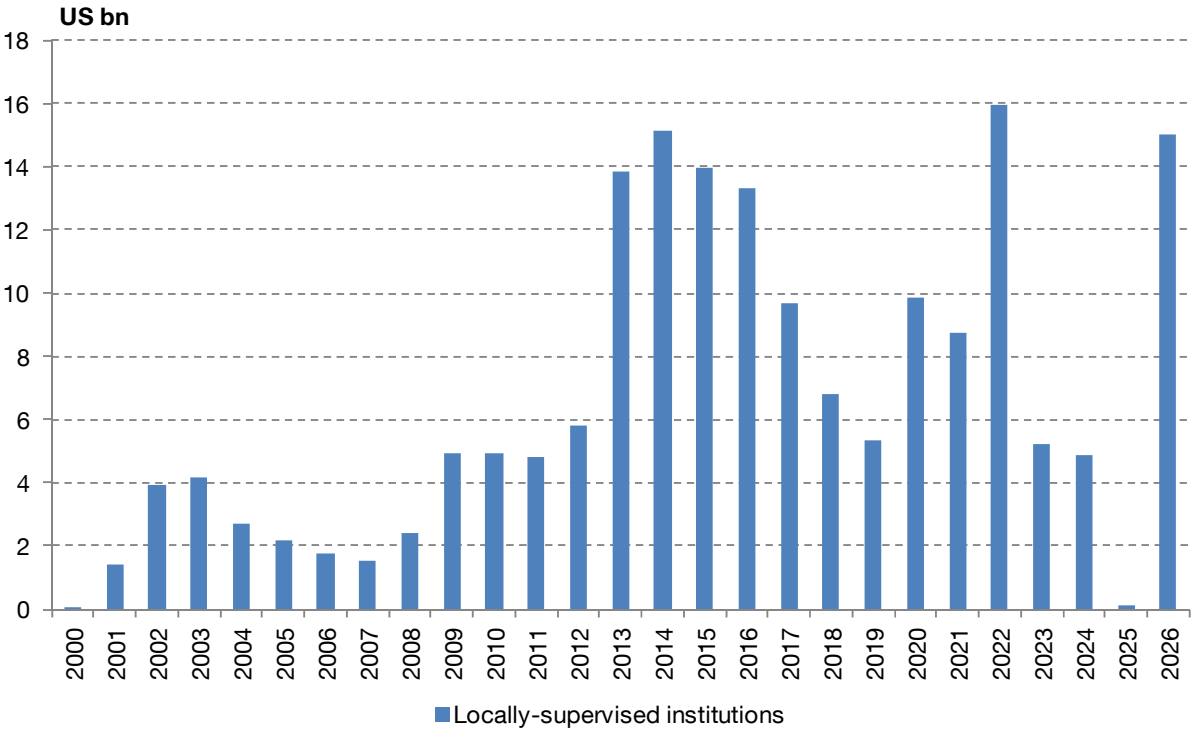

Source: Bloomberg, own elaboration

This leads to the next question. How easy is for banks to rollover existing debt? In addition to banks' own liquidity and solvency conditions, the answer undoubtedly involves the holders of these debt securities. Although we do not have data on the composition of Latin America's international debt holders, recent reports indicate that a significant proportion is held by traditional long-only international institutional investors, such as mutual funds and pension funds (although hedge funds and individual buyers also play a role) (see, IMF (2014a). As discussed in section III, the attainment of investment grade-status by a number of Latin American sovereigns during the pre-crisis period (2007-09) facilitated the demand for debt securities by institutional investors from advanced economies (the large majority of international debt issuances by Latin American banks were in the form of investment-grade bonds). The issue is whether the behavior of institutional investors has a smaller tendency towards procyclicality as international banks. As pointed out by Shin (2013), from the emerging markets' point of view the distinction between whether leverage institutions or long-only investors hold their debt is less important if both types of institutions have a similar procyclical behavior. This is an empirical question and there is not sufficient research on the subject.

Notwithstanding insufficient information, there are reasons to believe that in the face of an adverse shock affecting emerging markets institutional investors will sell these countries' bonds in the secondary market quickly and on large magnitudes. If the perception of emerging markets' risk deteriorates significantly, asset managers have the incentive to reduce their emerging market positions based on the argument that expected growth in these countries has declined (Shin, 2013). A fortiori, they will not rollover maturing debt securities. ${ }^{43}$

The pervasive effects of a sell-off of Latin America's corporate bonds would go beyond the increase in the international cost of funding. Rojas-Suarez and Sotelo (2007), show that external debt plays a central role in the behavior of domestic interest rates in Latin America, through its effect on country risk. Thus, the pass-through from external

43. Thus, to a large extent, the reduction in credit exposures by international banks that would follow an adverse shock to emerging market would have a similar effect on these countries funding costs than a cut back in emerging markets' corporate bonds by asset managers of investment funds. 
costs of funding to internal costs is large in the region. This, in turn, often translates in lower economic growth.

\section{Box 1. Banks' Usage of External Issuances of Debt.}

The burst in international debt securities issuances by Latin American banks opens an additional question: to which activities are banks allocating these proceeds? Unfortunately, there is a lack of systematic information about the usage of banks' external debt. However, some evidence suggests that in some countries banks might be using part of the proceeds from their increasing external indebtedness to fund their international expansion. ${ }^{44}$ For example, the Central Bank of Brazil has argued that a substantial part of Brazilian banks' international issuances are held overseas (BCB (2014)), and probably used to lend corporate clients. This assessment is consistent, as well, with the take-off in the process of banks internationalization (see CGFS (2014a). Some Latin American banks are, perhaps, taking advantage of the retrenchment of advanced economies' global banks.

The existing information on Latin American banking systems international claims (i.e., cross-border claims plus local claims in foreign currency) supports this assessment. The BIS International Banking Statistics gathers information of domestic (national) banks' international claims, for three countries -Brazil, Chile, and Mexico-, although it does not provide information on foreign-owned banking groups incorporated in the region, nor for Colombia or Peru-. Accordingly, the existing data should be interpreted as a lower bound. ${ }^{45}$ In any event, Latin American banks' international claims already amount to over US\$100 billion, and have increased steadily after the global financial crisis. This cross-border lending by Latin American banking systems could be particularly important in some financial market segments, and a key driver of medium-tier firms' internationalization (CGFS (2014b). That is, while LatinAmerica top-tier firms are able to tap markets as well as banks, the rest of the companies are probably served solely by Latin American banks.

So, what could be expected if banks' ability to tap markets at the rate of recent years fades, or if they fail to rollover existing debt? Tackling these issues is complex and beyond the scope of this paper. The information is scant, but it cannot be ruled out that a reversal in funding conditions could have the potential to impair relevant business lines. In this regard, Brazil and Colombia are two of the countries with the highest degree of internationalization in Latin America. In particular, the participation of Colombian banks in Central America is noticeable.

These concerns are reinforced by data showing a large concentration in the market for corporate bonds. This is also the case for Latin American banks' corporate bonds, which are probably concentrated in a few asset managers. For example, according to an IMF (2014b) report, about 35 percent of Bancolombia SA's total international debt issuances are held by two funds: METLIFE and Doublel ine Capital.

44. As shown in Chart 7 , the rate of growth of domestic credit expansion (by both domestic and foreign banks) has remained stable in the post-crisis period and at levels below the pre-crisis period. This is consistent with the, at least partial, usage of Latin American banks' external indebtedness to finance international activities.

45. This information is not compiled for foreign-owned banking groups in Brazil, Chile, and Mexico; and Colombia and

Peru do not report to the BIS Consolidated Banking Statistics. 
To sum up, the data suggests a significant increase in roll-over risk by Latin American banking groups. A more precise assessment of the extent and impact of this risk requires an analysis of banks' availability and access to foreign currency liquidity. We partially come back to this issue in section 4.3.2.

High concentration in international bond markets and some indicators of procyclical behavior by institutional investors act as additional warnings to the already increased vulnerabilities by some Latin American banking groups who have combined their increased issuance of international debt with an overall increased reliance on wholesale funding.

\subsubsection{CENTRAL BANKS' CAPACITY TO RESPOND TO EXTERNAL SHOCKS}

A crucial lesson learned by Latin American countries from the financial crises of the 1990s was the importance of counting on external liquidity as a means of reducing vulnerability to sudden shifts in investors sentiments in the international capital markets. Central banks external liquidity is perceived as complementary to potential liquidity provision by the International Monetary Fund, other multilateral organizations and bilateral swaps arranged with central banks from advanced economies, especially the US Fed.

Aware of the need for self-insurance, Latin American countries accumulated large amounts of international reserves in the 2000s. From 2002 to 2007 -the pre-global crisis year-international reserves almost tripled in the region. This strategy combined with an improved management of the maturity structure of sovereign international debt served Latin American countries well during the global financial crisis. Proof of liquidity supported investors' confidence in the region's ability to stand the shock, especially during the period where internationally liquidity dried up.

Although central banks in the region continued accumulating international reserves in the post-global crisis period (facilitated by the commodity boom that lasted until 2013), the rapid increase in issuances of external debt securities has weakened the relative strength of a number of central banks to deal with an adverse external shock. Latin American banks' external debt can constitute a potential source of foreign-currency needs. Since banks are engaged in maturity transformation, even if they do not have currency mismatches, they can face potential liquidity problems in foreign currency. Hence, it is important to measure Latin American debt relative to international reserves.

\section{CHART 13 LATIN AMERICAN BANKS OUTSTANDING EXTERNAL DEBT. AS \% OF INTERNATIONAL RESERVES}

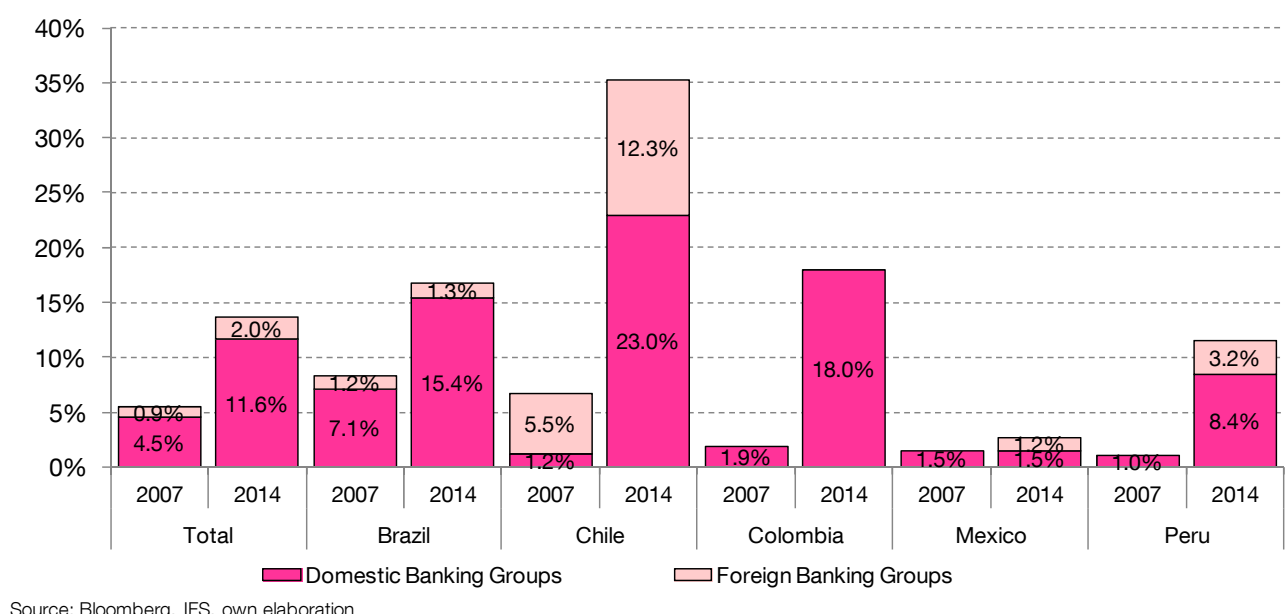

Source: Bloomberg, IFS, own elaboration 
Chart 13 compares the ratio of Latin American banks' external debt to international reserves in 2007 and 2014 for the five countries in our sample. The ratio has deteriorated in all the countries, albeit at different degrees. Mexico experienced the least weakening among countries in the sample. In contrast, banks' external debt in Chile represents a substantial fraction of international reserves, largely because of the increase in debt by both domestic and foreign banking groups. It is also worth mentioning the deterioration of the ratio in Brazil and Colombia; mainly because of outstanding external debt by domestic banking groups. ${ }^{46}$

Banks' external- debt securities have also gained relative importance among potential sources of pressure on central banks' international reserves. This is apparent in chart 14, which breaks down external debt, measured as percentage of international reserves in 2007 and 2014. ${ }^{47} 48$ Outstanding external debt by governments represents a lower fraction of international reserves, as happens with cross-border bank loans on non-banks. This is consistent with the trends in financial integration discussed in section II. The opposite happens with external debt securities by banks, non-financial corporations, and other financial corporations, which have gained importance as a proportion of foreign reserves. Their relative importance varies across countries: banks' external debt securities are more important in Brazil, and Chile, and less so in Mexico, where external funding by non-financial corporations dominates. Peru stands out as the country with lower external debt relative to reserves -since its holdings are very large relative to its potential usage.

CHART 14. LATIN-AMERICA. TOTAL EXTERNAL DEBT AS \% OF INTERNATIONAL RESERVES

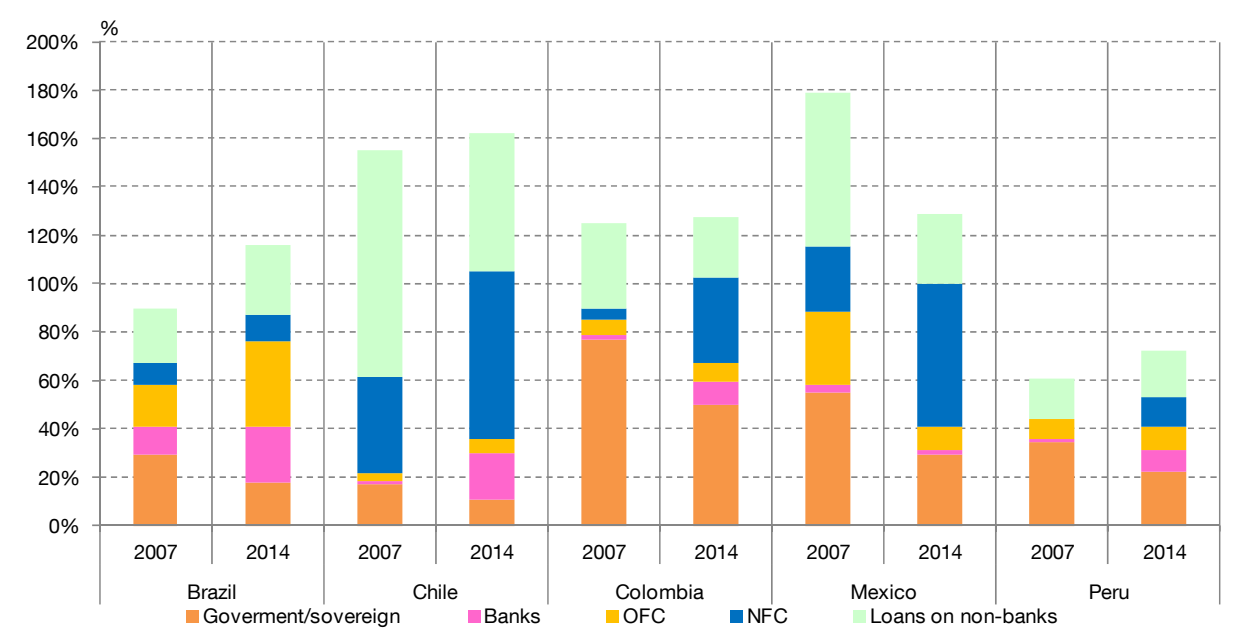

Note: Debt securities issuances by Government,/sovereign banks, OFC, NFC. NFC stands for non-financial corporations; OFC stands for other financial corporations.

46. Among other Emerging Economies, Russia, Qatar and Turkey stand out for the large increase in the ratio of banks' external debt to foreign exchange reserves between 2007 and 2014. Over the same period, the increase in Latin America as a region is similar to that in the group of other Emerging Economies (see Annex III).

47. The traditional vulnerability indicator is the ratio of short-term external debt to international reserves. In this exercise, we use, instead, total external debt in the numerator of the indicator because if rollover risks materialize, debtors might need to demand large amounts of dollars to meet their maturing external obligations on debt (being it short or longterm). Moreover, sharp increases in a country's rollover risk induce a selloff of that country's debt securities in the secondary markets, which exacerbates deteriorated perceptions of country risk and fuels capital outflows. The larger the stock of outstanding debt, the greater the adverse effect on country risk. These developments press drastically on central banks' international reserves (and the exchange rates).

48. The breakdown serves as an approximation only, since it uses data from different sources. Banks' external debt is obtained from our measure of "locally-supervised institutions", which includes debt issued by banks' foreign offices. These offices could be incorporated as financial vehicles, and as such classified as well as "other financial corporations". These data are obtained from the aggregate measures published by the BIS. 
Thus, the message from charts 13 and 14 is that in the post-crisis period the significant increase in external indebtedness of banks-who were small players in the international capital markets in the pre-crisis period--has undermined central banks' efforts to increase the resilience of their local economies to external financial shocks. This has been exacerbated by the already established and very active role of non-financial corporations as issuers of external debt. 


\section{Conclusions}

This paper analyzes the shifts in Latin American banks' funding patterns in the post-global crisis period. For that purpose, we develop a new measure of exposure of local banking systems to international debt markets. In contrast to well-known BIS measures, our new metric includes all entities that fall under the supervisory purview of the local authority. This is especially important in Latin America, where the participation of foreign banks is very large and these banks are established as independent, fully-capitalized entities. We call this metric: International Debt Issuances by Locally-Supervised Institutions. This indicator includes the international debt issued by domestic banking groups and foreign-owned banking groups which comprises the institutions incorporated locally as well as their domestic and foreign affiliates.

Using this metric we found that banking groups in the five countries in our sample, Brazil, Chile, Colombia, Mexico and Peru, significantly increased their issuance of international debt securities since 2010; the suddenness of the increase indicating that the latter has not been the result of a process of banking sectors' deepening and development. Our new aggregate shows that the international issuance of debt by banking groups was larger than any of the two alternative BIS metrics suggests.

Should the rapid expansion of international debt issuances by Latin American banking groups be a reason for concern?

Although the solid banks' solvency ratios and improved supervisory capacity are certainly important factors supporting banking sectors' resilience to external shocks, a preliminary analysis of risks derived from the recent rapid rise of banks' external indebtedness reveals the emergence of several signs of increased vulnerability. Signals of vulnerabilities, however, are stronger in some countries than in others. For example, Brazil stands out since the expansion of banks' external debt has been accompanied by an increased reliance on wholesale funding by both domestic and foreign banking groups. These groups of banks have increased their vulnerability to adverse international shocks. In contrast, domestic banks in Colombia have offset their increase in external debt with a decline in other sources of wholesale funding. As a result, their ratios of wholesale funding to total liabilities remained stable during the post-global crisis period. In Peru, although banking groups have significantly increased issuance of external debt, their overwhelming reliance on domestic deposits as a funding source (over 70 percent) strongly supports the strength of the banking system to external shocks.

Distinguishing by ownership, at the regional level, there does not seem to be a clear differentiation between foreign banking groups and domestic banking groups with respect to their vulnerability to external shocks.

There are some additional reasons for concerns. Inter alia, this paper highlights two of them. First, the data indicate that rollover risks have significantly increased for Latin American banking groups. Maturing debt, which increased significantly in the period 2013-14, will continue at high levels in 2015 and beyond. In the context of high concentration in international bond markets and indicators of procyclical behavior by institutional investors, an adverse shock to emerging markets debt securities, such as an increase in the US Fed 
interest rate, will, most likely, drastically reduce the willingness of international investors to rollover Latin American banks' maturing debt securities. Rollover risk is particularly important in Brazil and Chile where the ratios of maturing debt securities debt to external debt are among the highest in the region, and high also in absolute terms.

Second, in spite of the large accumulation of international reserves by Latin American central banks, the large increase in banks' external debt, together with the large increase of external debt by corporations, in the post-crisis period might have reduced the resilience of central banks to deal with a severe adverse shock. Indeed, the ratios of banks' external debt to reserves have deteriorated in all countries in the sample relative to the pre-crisis period.

This paper has shed some light on emerging risks that might weaken the strength of Latin American banking systems if the presence of an adverse external shock, such as a large and sudden increase in interest rates by the US Fed were to take place. However, a full assessment of risks associated with the rapid increase in banking groups' issuance of external debt requires additional analysis involving the full balance sheets of banking groups and their clients. We hope that this paper encourages much needed further research. 


\section{REFERENCES}

BCB (BANCO CENTRAL DE BRASIL), (2014),"Relatório de Estabilidade Financiera. Marco 2014. Vol 13. N 1".

BASEL COMMITTEE ON BANKING SUPERVISION (2014) "Basel III: The Net Stable Funding Ratio", January (2012) "Joint Forum: Principles for the Supervision of Financial Conglomerates", Bank for International Settlements, September.

BERNANKE, B. (2013), "Long-Term Interest Rates", Remarks by Ben S. Bernanke at the Annual Monetary/Macroeconomic Conference Federal Reserve Bank of San Francisco.

ECONOMIC COMMISSION FOR LATIN AMERICA AND THE CARIBBEAN (2014), "Capital Flows to Latin America and the Caribbean," Washington DC, August.

CALVO, GUILLERMO, LEONARDO LEIDERMAN and CARMEN REINHART (1996) "Capital Flows to Developing Countries in the 1990s: Causes and Effects" Journal of Economic Perspectives, 10, Spring 1996, 123-139

CERUTTI, E., S. CLAESSENS, and P. MCGUIRE (2011), "Systemic Risks in Global Banking: What Available Data can tell us and What More Data are Needed?" IMF WP 11/222.

CERUTTI, E. (2013), "Banks' Foreign Credit Exposures and Borrowers' Rollover Risks: Measurement, Evolution and Determinants" IMF WP 13/09.

CGFS, (2014a), "EME banking systems and regional financial integration" CGFS Publications No 51, March 2014

CGFS, (2014b), "Summary follow-up workshops on EME banking systems and systems and regional financial integration" CGFS Publications No 51a, December 2014.

CLAESSENS, S. and N. van HOREN, (2014), "The Impact of the Global Financial Crisis on Banking Globalization," IMF Working Papers 14/197, International Monetary Fund.

FIECHTER, J., I. ÖKTER-ROBE, A. ILYINA, M. HSU, A. SANTOS, and J. SURTI (2011), "Subsidiaries or Branches: Does One Size Fit all? IMF Working Paper 11/04.

FORBES, KRISTIN and FRANCIS E. WARNOCK (2012) "Capital Flow Waves: Surges, Stops, Flight and Retrenchment" Journal of International Economics, 88(2): 235-251.

FUERTES, A. and J.M. SERENA (2014), "Firms Financial Soundness and Access to Capital Markets", Banco de España Financial Stability Review November n²7 Gruic. B. and P. Wooldridge (2013), "Who is issuing international bonds denominated in emerging market currencies?", Box 2, BIS Quarterly Review December 2013.

GALINDO, A., A. IZQUIERDO, and L. ROJAS-SUÁREZ (2010), "Financial Integration and Foreign Banks in Latin America: How Do They Impact the Transmission of External Financial Shocks?," Research Department Publications 4651, Inter-American Development Bank, Research Department.

GUIDOTTI, PABLO and LILIANA ROJAS-SUAREZ (2011) "Learning from Past Mistakes: The Key to Latin America's Financial Systems Resilience to the Global Financial Crisis", in World in Crisis: Insights from six Shadow Financial Regulatory Committees from Around the World, edited by Robert Litan, FIC Press, Wharton Financial Institutions Center, November.

INTER-AMERICAN DEVELOPMENT BANK (2014), "Global Recovery and Monetary Normalization: Escaping a Chronicle Foretold?" 2014 Latin American and Caribbean Report, coordinated by Andy Powell. Inter-American Development bank, Washington DC.

INTERNATIONAL MONETARY FUND (2014a), "Global Financial Stability Report, Washington DC, April International Monetary Fund (2014b), "Global Financial Stability Report, Washington DC, October.

INTERNATIONAL MONETARY FUND (2014c), "Regional Financial Outlook Update, Western Hemisphere", Washington DC, October.

LAM, R. W. (2013), "The Cross-Border Activity of Japanese Banks", IMF Working Paper 13/235.

MCCAULEY, ROBERT, CHRISTIAN UPPER and AGUSTIN VILLAR (2013) "Emerging Debt Securities Issuance in Offshore Centres", in BIS Quarterly Review, September.

MCCAULEY, ROBERT, PATRICK MCGUIRE, and VLAD SUSKHO (2014), "Global dollar credit and links to US monetary policy and leverage" paper prepared for the 59th Economic Policy Panel.

MCGUIRE, P. and G. VON PETER (2009), "The US dollar shortage in global banking and the international policy response" BIS Working Paper $n^{\circ} 291$.

RODRIGUEZ-BASTOS, F., H. KAMIL, and B. SUTTON (2015, "Corporate Financing Trends and Balance-Sheet Risks in Latin America: Taking Stock of "The Bon(d)anza", IMF Working Paper n 15/10.

ROJAS-SUÁREZ, L. (2007), "The Provision of Banking Services in Latin America: Obstacles and Recommendations", Working Papers 124, Center for Global Development.

ROJAS-SUAREZ, LILIANA and SEBASTIAN SOTELO (2014), "The burden of Debt: An Exploration of Interest Rate Behavior in Latin America”, Contemporary Economic Policy, Vol. 25. No. 3, pp.387-414.

SHIN, HYUN SONG (2013) "The Second Phase of Global Liquidity and its Impact on Emerging Economies", Keynote Address at the Federal Reserve bank of San Francisco Asia Economic Policy Conference. Princeton University, November.

THE ECONOMIST, 2014, Our Crony-capitalism Index: The countries where politically- connected businessmen are most likely to prosper, March 15, HTTP://WWW.ECONOMIST.COM/NEWS/INTERNATIONAL/21599041-COUNTRIES-WHEREPOLITICALLY-CONNECTED-BUSINESSMEN-ARE-MOST-LIKELY-PROSPER-PLANET.

TURNER, PHILIP (2014) "The Global Long-Term Interest rates, Financial Risks and Policy Choices in EMEs”, BIS Working Paper No. 441, Bank for International Settlements, February.

VAN HOREN, N. (2012), Branching out: The rise of emerging market banks, in: Financial Development Report, World Economic Forum, 47-54. 


\section{Annex I: Net External Financing: Other Emerging Economies}

This Annex shows the shifts in net external financing in a group of other Emerging Economies, using the BIS Debt Securities Statistics. This group is composed by India, Indonesia, South Korea, Malaysia, Philippines, Qatar, Russia, Thailand, and Turkey. For this group as a whole, Panel I depicts the ratio of net external financing to GDP, broke down between debt securities issuances by banks and non-banks and loans on banks and on non-banks. Panel 2 breaks down international debt issuances by sector.

CHART I. OTHER EMERGING ECONOMIES. EXTERNAL FINANCING PATTERNS PANEL 1. NET EXTERNAL FINANCING

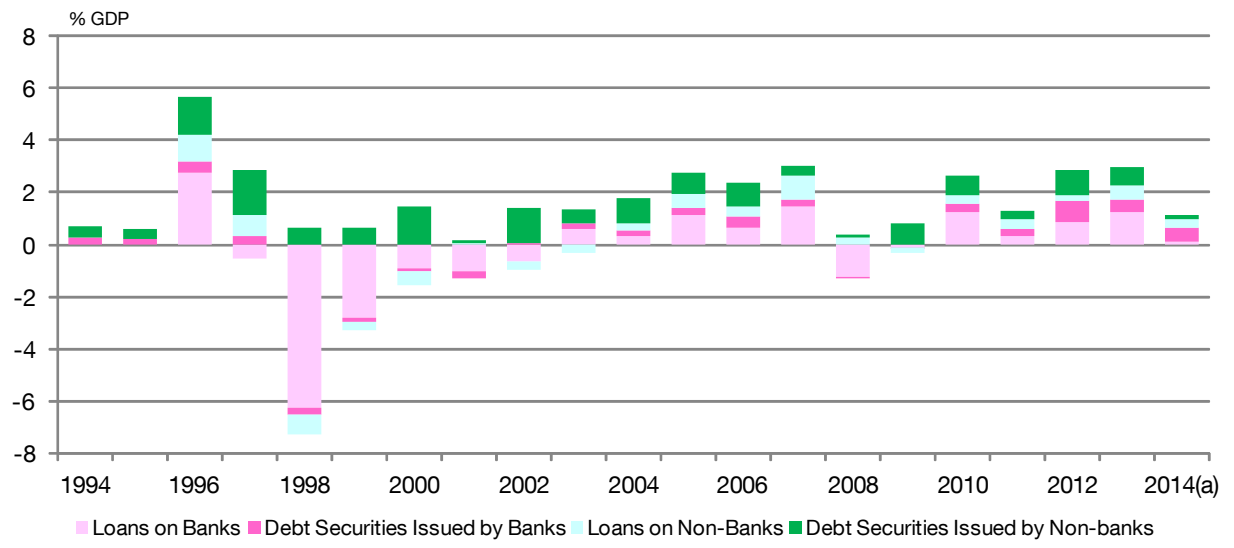

Source: BIS Intemational Debt Securities Statistics; BIS International Banking Statistics, WEO.

(a) Annualized. Information available only up to the third quarter.

PANEL 2. INTERNATIONAL DEBT SECURITIES ISSUANCES. BREAKDOWN BY SECTOR

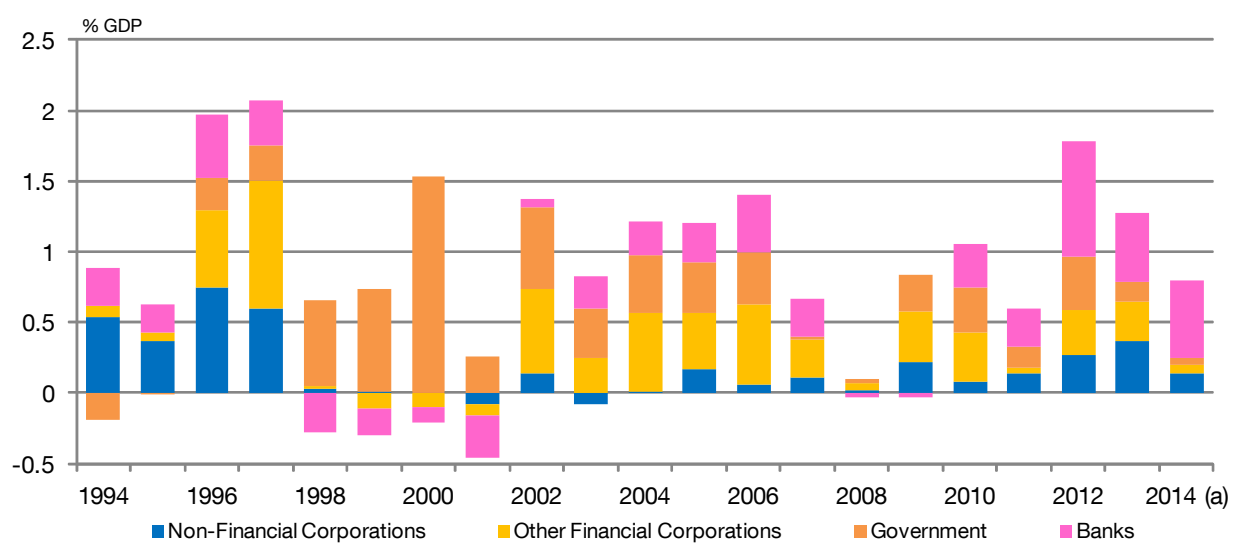

Source: International Debt Securities Statistics, by Nationality.

(a) Annualized. Information available up to the third quarter. 


\section{Annex II. Data Issues}

1. Tracking international Debt Securities Issuances: we gather deal-level data on international debt securities issuances using Bloomberg.

- Locally-supervised institutions: Our focus is on locally-supervised institutions, therefore including both domestic and foreign-owned banking groups. To identify locally-supervised institutions, we look at banking groups' corporate structure, and the legal relationships between parents and their affiliates. This allows identifying foreign-owned banking groups under the purview of local supervisors. In Latin America all foreign-banks are locally-supervised. In other emerging economies there are foreign banks which are not legally incorporated as locallysupervised institutions. Hence, we are not investigating their funding patterns.

- Offshore financing of locally-supervised institutions: We are accounting for banking groups' offshore issuances -i.e., debt issued by foreign offices-, as long as they are guaranteed by their banking group. To determine this, we focus on the relationship between the banking group (either domestic or foreign) and its foreign-affiliate: if the banking group supports its affiliate, we consider it is also guaranteeing its debt.

- Sector classification: we are focusing on banking groups' funding patterns, so we account for all their affiliates funding in international markets -as long as they are supported by their banking groups. Hence, we are gathering as well funding obtained from non-bank affiliates. This includes offshore financing by financial vehicles owed by banking groups, which might be prominent in some institutions. This implies our data is not strictly comparable with aggregate statistics on debt funding (i.e., BIS Debt Securities Statistics) where deals are classified using the issuer's sector (instead of that of the parent company).

- Instrument coverage: we obtain data for all types of securities: corporate bonds, medium-term notes, and private placements. In Latin America, a number of banking groups obtain financing through medium-term notes. Therefore, looking at corporate bonds would miss an important fraction of debt issued at international markets.

- Measurement criteria: Since we have data at the deal level, we are able to group it by different criteria. Besides our favourite measure, we group data by residence and by nationality. In Latin America, by construction, debt by locallysupervised institutions is higher than the largest of the other two measures.

- Computing stocks and net flows: we compute net flows using information on the maturity of debt securities. In the same vein, we compute outstanding external debt. We are not able to control for liability management operations.

2. Bank Liability Structure: to investigate banking groups funding patterns we look first at SNL bank-level information. Our focus is on the liability structure.

- Liability breakdown: we focus on Total Financial Liabilities, and break them down between 1) Core Liabilities; 2) External Wholesale Funding; and 3) Wholesale Funding excluding External Debt. We define Core Liabilities as Total Deposits, minus Interbank Deposits. External Wholesale Debt is constructed using the deal- 
level information from Bloomberg. Wholesale Funding is equal to Total Financial Liabilities, excluding Total Deposits, plus Interbank Deposits. Accordingly, it includes the following instruments: Total Debt, Interbank Deposits, Derivative Liabilities, Securities Sold, not yet Purchased, and Other Financial Liabilities. Interbank Deposits are deposits from other banks. Wholesale Funding excluding External Debt is the difference between Wholesale Funding and External Wholesale Debt. We leave aside Non-Financial Liabilities, which includes Separate Account Liabilities, Insurance Liabilities, Noncurrent Asset Retirement Obligations, Non-Current Liabilities HFS \& Discontinued Ops, Tax Liabilities, Other Provisions, Total Other Liabilities.

- Banks under analysis: We use information of locally-supervised institutions (including domestic and foreign-owned banking groups). As said before, we use banking groups' corporate structure to classify foreign institutions between locally-supervised and under home surveillance. While in Latin America all foreign banks are locally-supervised, in other emerging economies there are some institutions which fall into the other category. For domestic banking groups, we focus on the consolidated level (i.e., a parent institution and all its affiliates). For foreign banking groups, we focus on that institution and its affiliates. 


\section{Annex III. Funding patterns of other emerging economies banks}

In this annex we show preliminary evidence on funding patterns by banks in other emerging economies, using information gathered by Bloomberg. Chart III.1 shows the increase in gross international securities issuances by locally-supervised institutions, and by nationality. The relative small difference between the two metrics indicates the relatively (to Latin America) small participation of foreign banking groups.

\section{CHART III.1. OTHER EMERGING ECONOMIES BANKS GROSS INTERNATIONAL DEBT} SECURITIES ISSUANCES. ALTERNATIVE METRICS

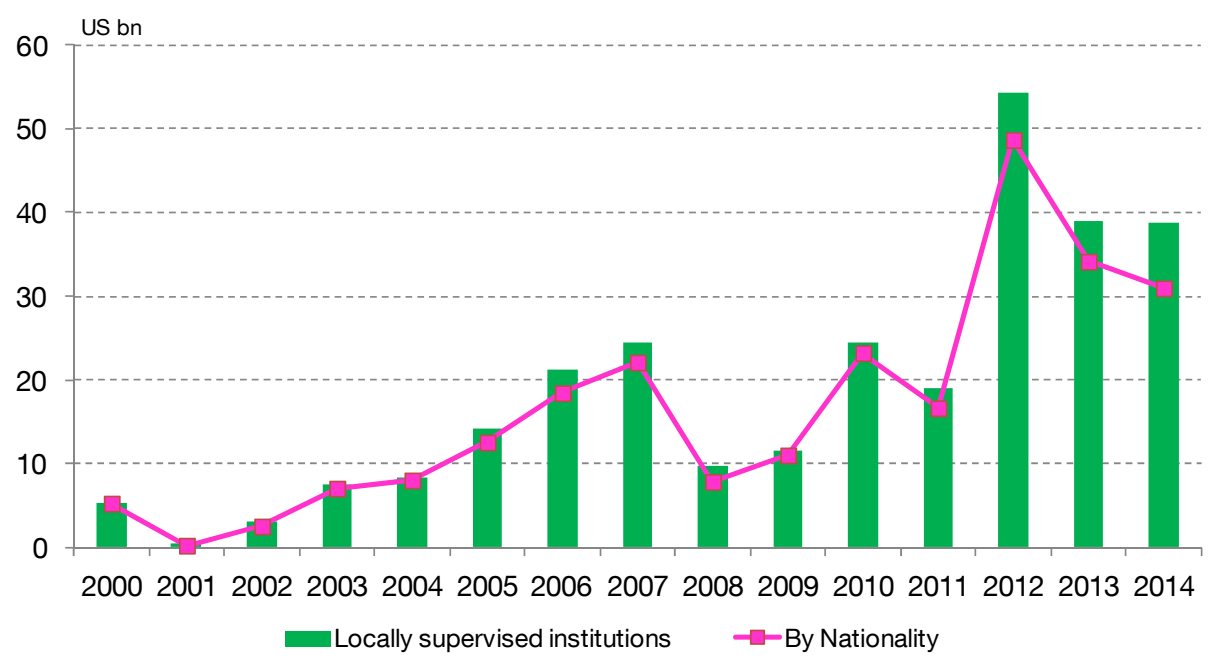

Source: Bloomberg, own elaboration.

Chart III.2 shows gross international debt securities issuances by domestic and foreign banking groups: while both have increased, issuances by domestic banking groups are much larger in absolute terms.

\section{CHART III.2. OTHER EMERGING ECONOMIES BANKS GROSS INTERNATIONAL DEBT SECURITIES ISSUANCES DOMESTIC AND FOREIGN BANKING GROUPS}

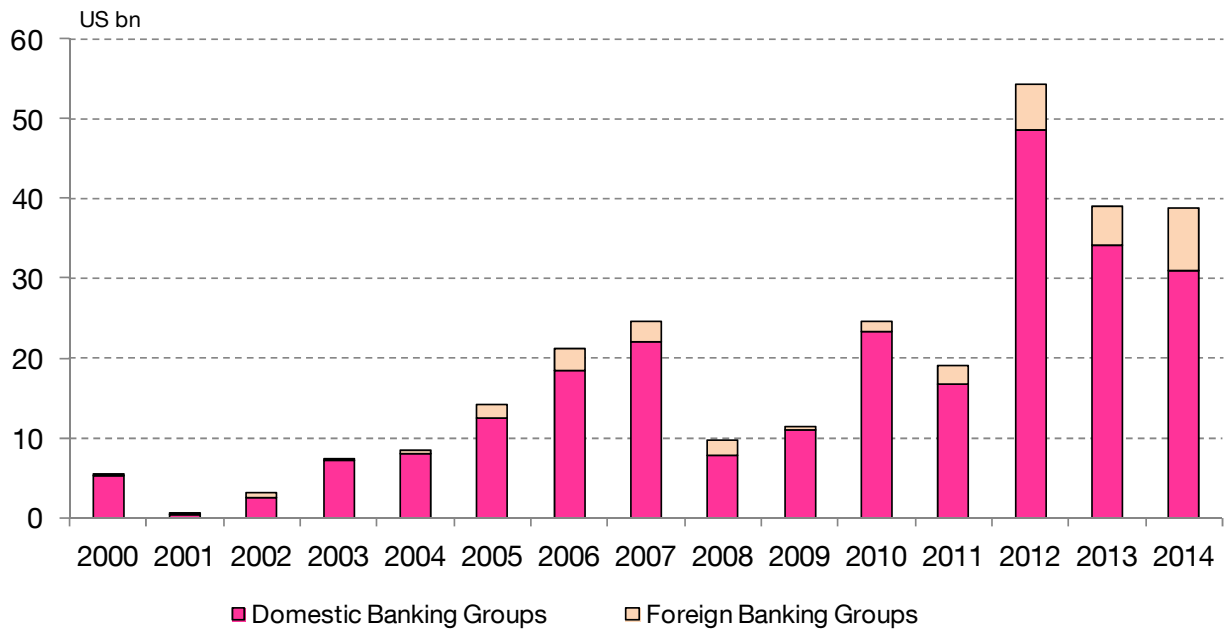

Source: Bloomberg, own elaboration 
However, when gross issuances are measured against total assets, foreign banking groups seem more active than domestic banking groups. Chart III. 3 shows that gross issuances amounted for $2.3 \%$ and $2.7 \%$ of total assets in domestic and foreign banking groups. As in Latin America, differences at the country level are large.

\section{CHART III.3. OTHER EMERGING ECONOMIES BANKS. BANKING GROUPS CUMULATED DEBT SECURITIES INTERNATIONAL DEBT ISSUANCES, 2010-2014 \\ AS \% TOTAL ASSETS}

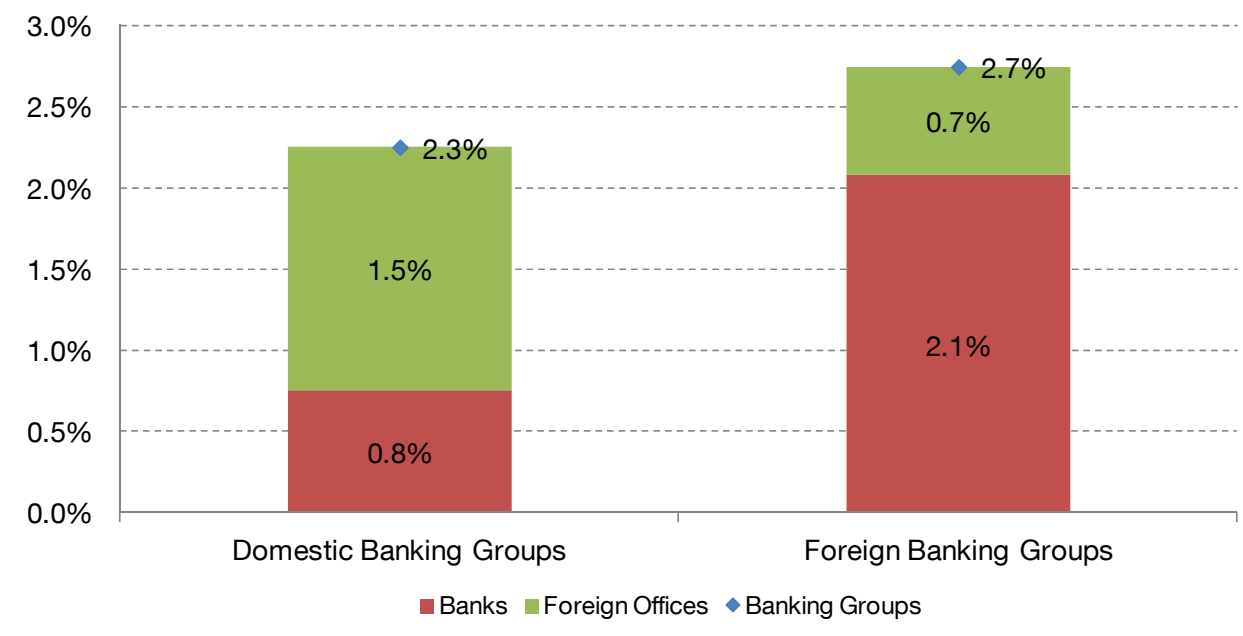

Source: Bloomberg, SNL, own elaboration.

Chart III.4 shows the shift in banks' liability structure: there is an increase in wholesale funding, to some extent driven by the increase in debt issued at international markets. As in Latin-America, the numbers are still low.

CHART III.4. OTHER EMERGING ECONOMIES BANKS' LIABILITY STRUCTURE. LOCALLYSUPERVISED INSTITUTIONS

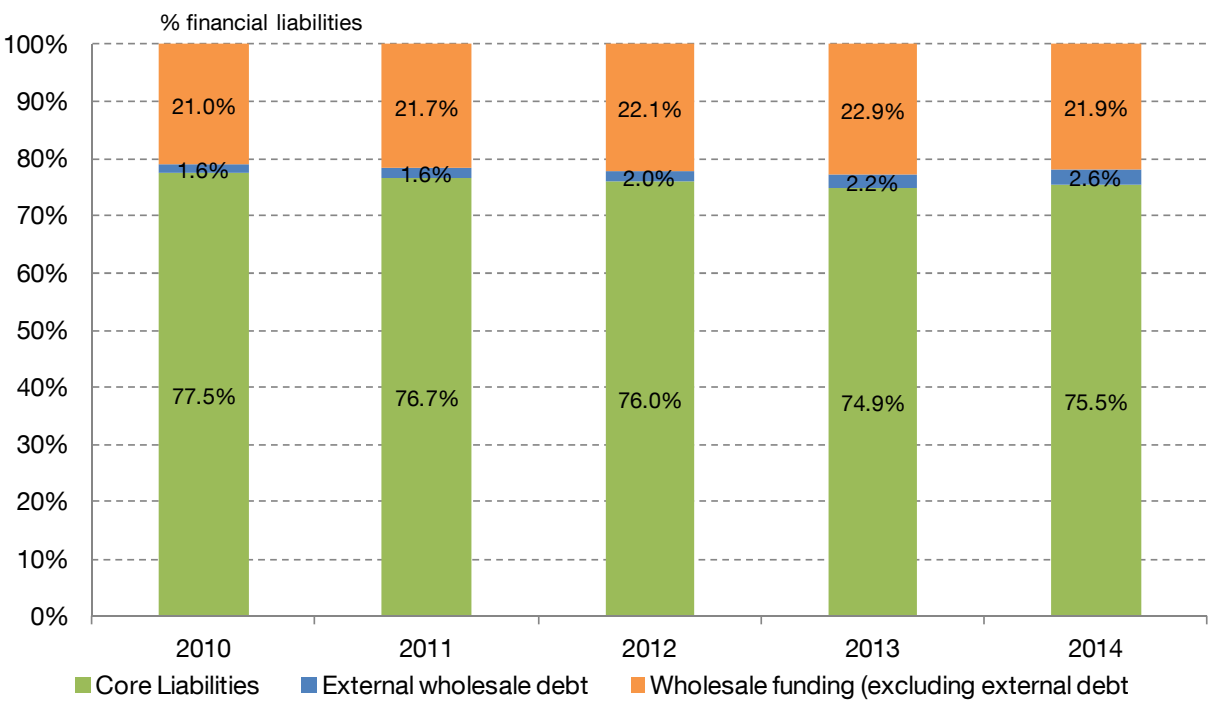

Source: Bloomberg, SNL, own elaboration. 
Chart III.5 shows that net debt issuances have also increased: in the last three years they have been three times larger than its peak before the global financial crisis. Redemptions have increased in the last two years.

\section{CHART III.5. OTHER EMERGING ECONOMIES BANKS NET DEBT SECURITIES} ISSUANCES AT INTERNATIONAL MARKETS

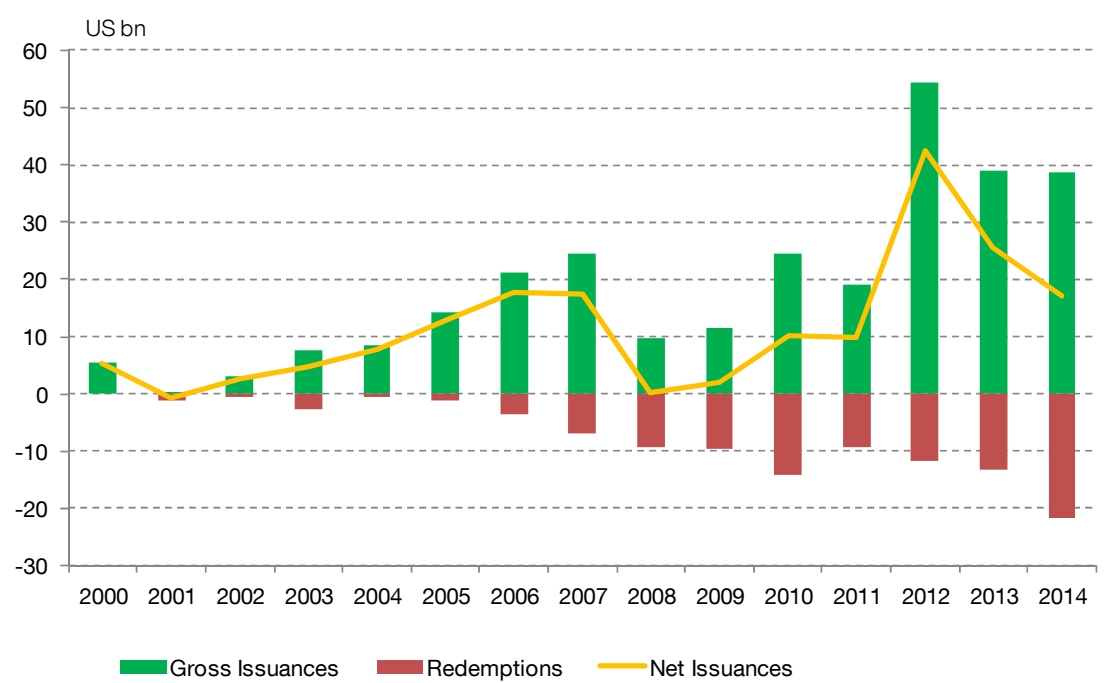

Source: Bloomberg, own elaboration.

Chart III.6 shows the maturity profile of banks' international debt: rollover risks are large in 2015-2019, and fade afterwards. Compared to Latin-America, the maturity profile is worse.

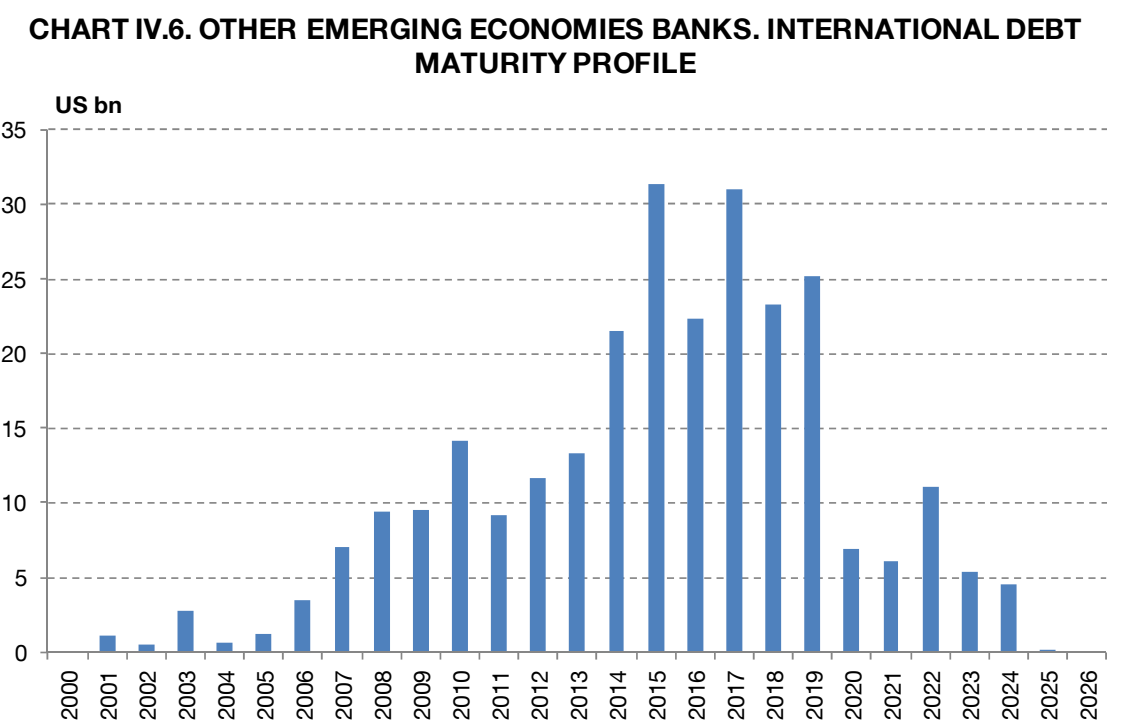

- Locally-supervised institutions

Source: Bloomberg, own elaboration

Chart III.7 measures banks outstanding debt relative to central banks' international reserves. In Qatar, Turkey, and Russia, debt is large relative to reserves. In most countries the bulk of debt is due to domestic banking groups. Turkey is an exception, since foreign banking groups account for half of total outstanding debt -more than $10 \%$ of reserves. 
CHART III.7. OTHER EMERGING ECONOMIES BANKS OUTSTANDING EXTERNALDEBT. AS \% OF INTERNATIONAL RESERVES

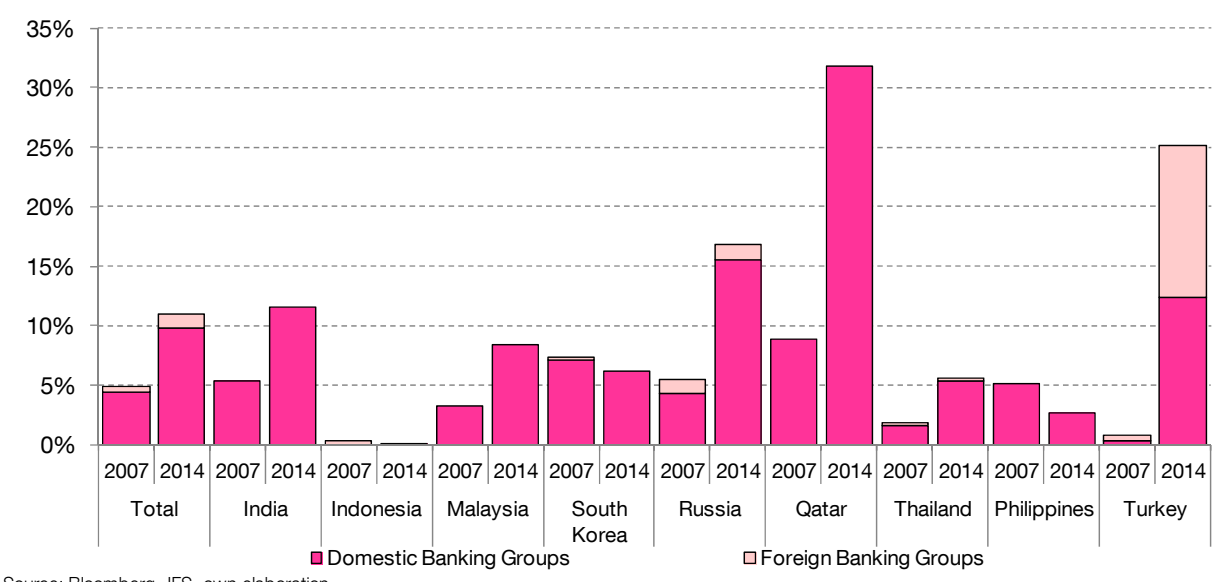
Source: Bloomberg, IFS, own elaboration

Chart III.9 shows gross international debt issuances relative to each country GDP.

\section{CHART III.8. OTHER EMERGING ECONOMIES BANKS GROSS INTERNATIONAL DEBT SECURITIES ISSUANCES AS \% GDP}

$$
\% \text { GDP }
$$

A. TOTAL ISSUANCES 2010-2014

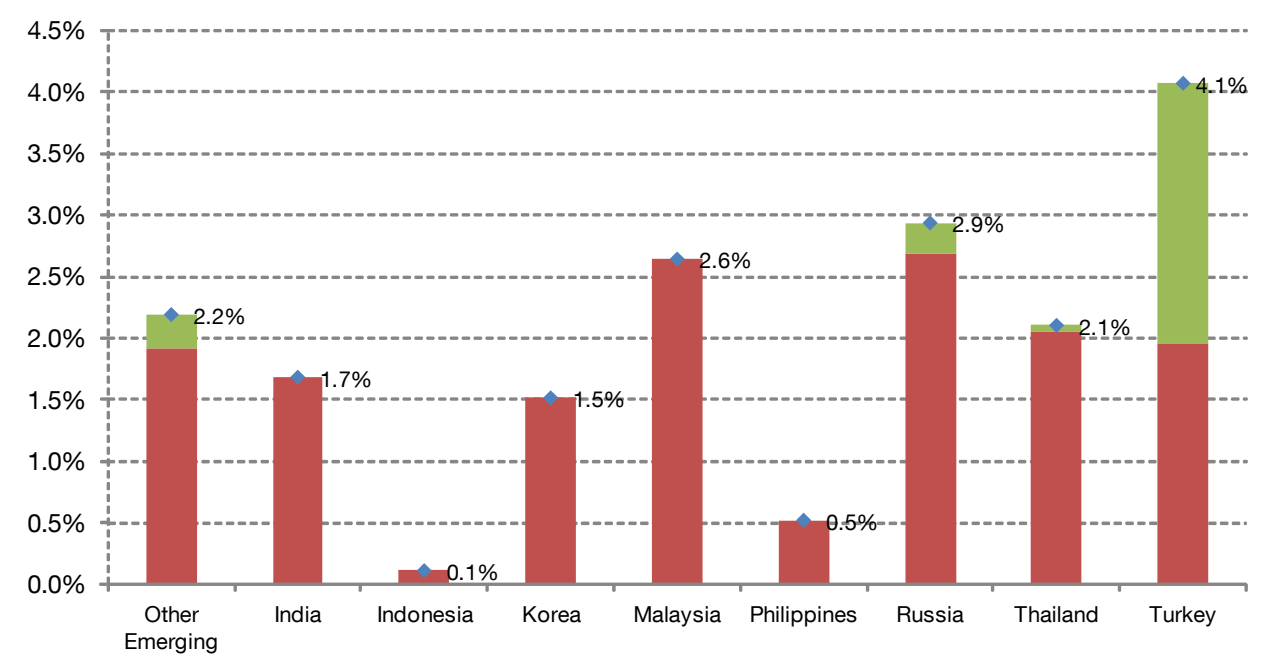

\section{$\begin{array}{ll}\% G D P & \text { B. TOTAL ISSUANCES 2000-2009 }\end{array}$}

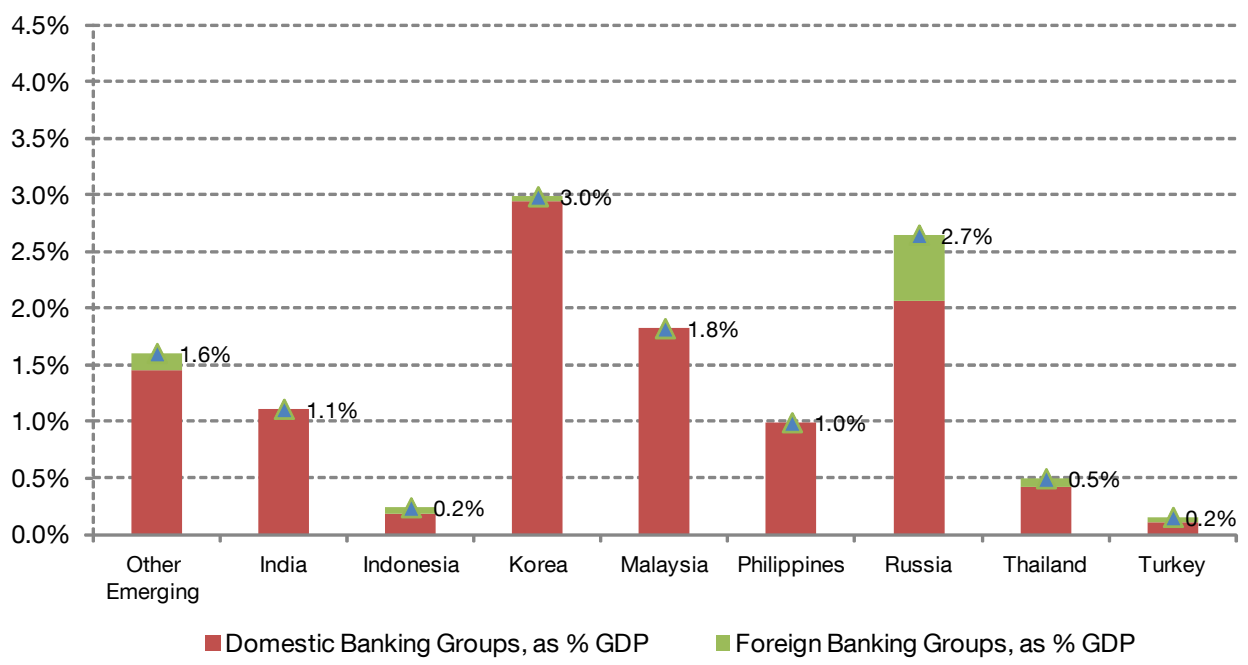

Source: Bloomberg, own elaboration 


\section{Annex IV: Gross International Debt Securities Issuance: Selected Latin American}

Countries

Chart IV shows gross international debt securities issuances, measured with the three alternative metrics: by residence, by nationality, and by locally-supervised institutions. The first panel reproduces chart 5 in the main text, and the remaining panels show information for each of the Latin-American countries under analysis: Brazil, Chile, Colombia, Mexico, and Peru.

\section{CHART IV.1. LATIN AMERICAN BANKS GROSS INTERNATIONAL DEBT SECURITIES ISSUANCES. ALTERNATIVE METRICS LATIN-AMERICA 5 BRAZIL}
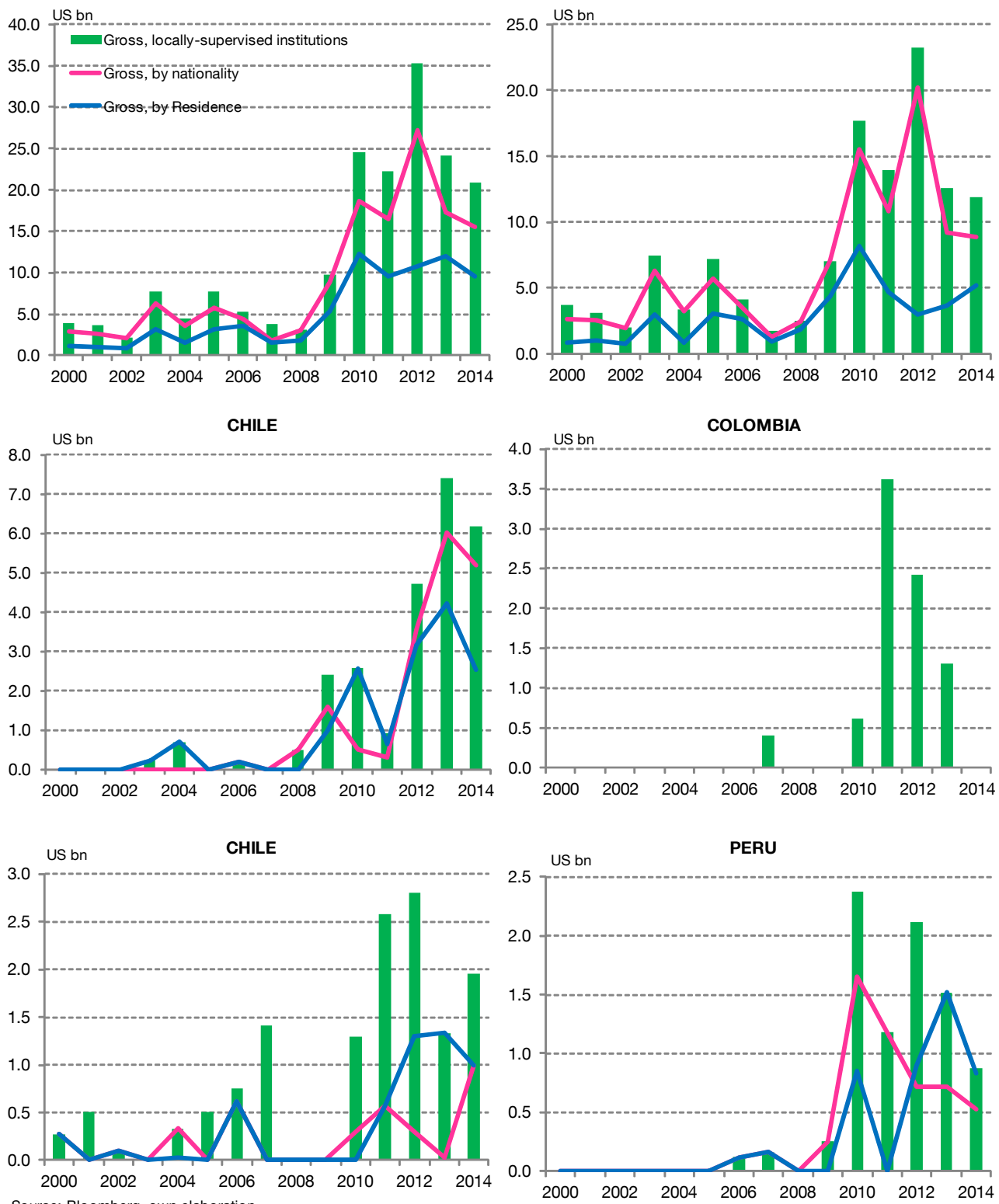

Source: Bloomberg, own elaboration.

Note: in Colombia the three metrics are equal, since all issuances are by domestic banks incorporated in Colombia 
CHART IV.2. LATIN AMERICAN BANKS GROSS INTERNATIONAL DEBT SECURITIES

ISSUANCES AS \% GDP
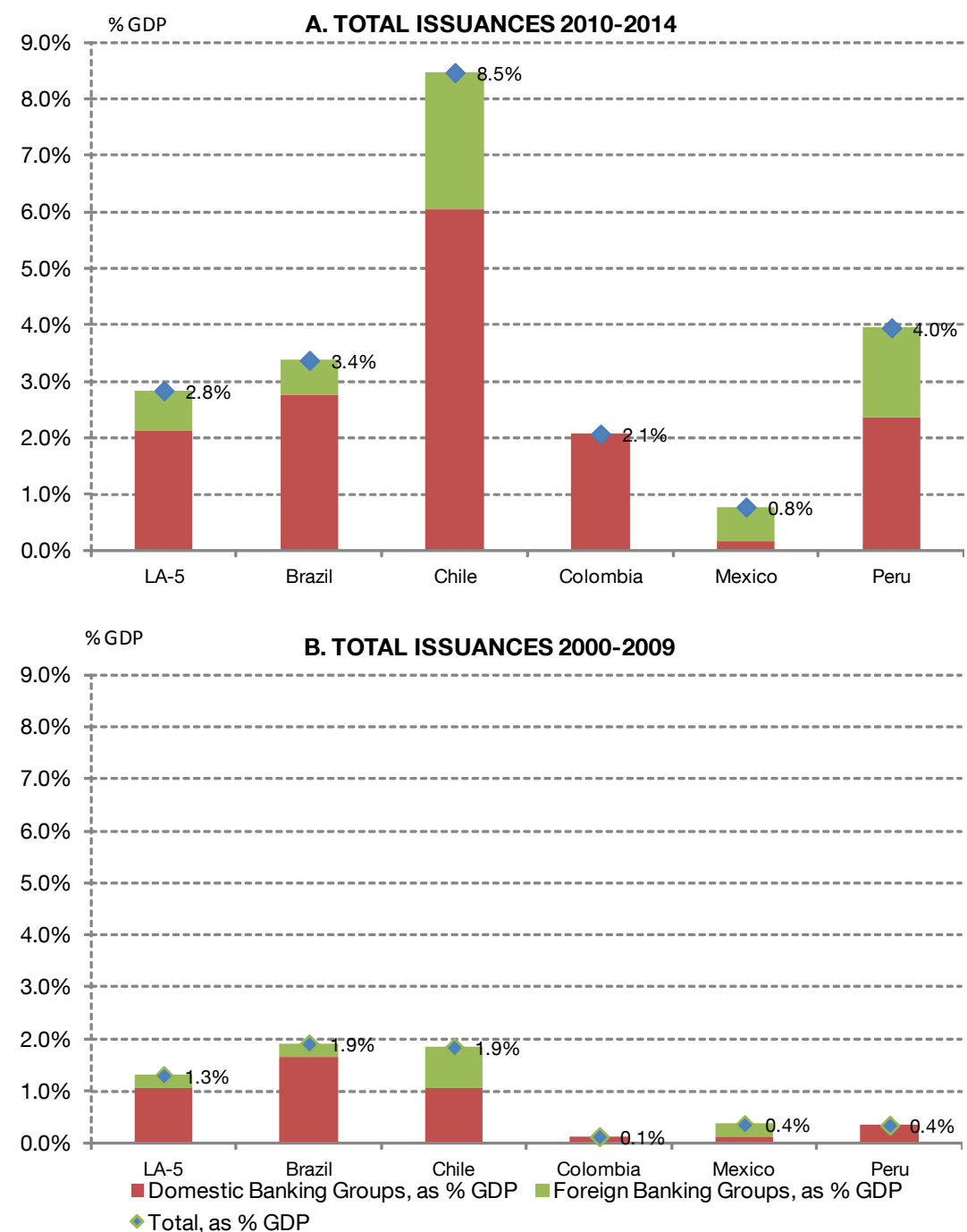

Source: Bloomberg, own elaboration. 


\section{Annex V: Ratio of International Debt Securities Issuances to Assets: Domestic vs Foreign Banking Groups}

Chart V depicts cumulated (2010-2014) international debt securities issuances relative to total assets for domestic and foreign-owned banking groups in each country of our sample. Within each banking group we also decompose cumulated issuances between those by banks and those by their foreign offices.

CHART V. BANKING GROUPS CUMULATED DEBT SECURITIES INTERNATIONAL DEBT ISSUANCES, 2010-2014 AS \% TOTAL ASSETS
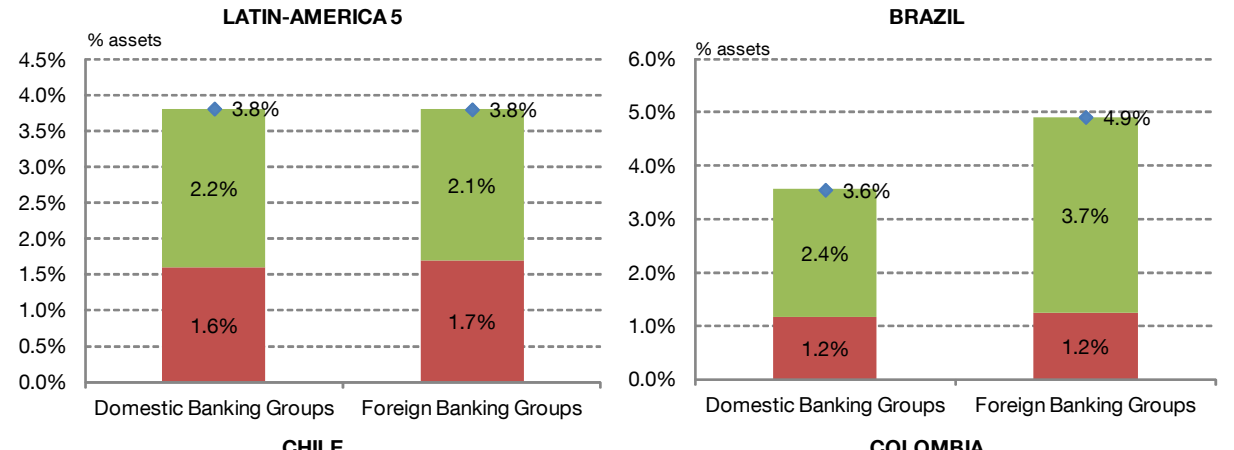

Domestic Banking Groups Foreign Banking Groups CHILE
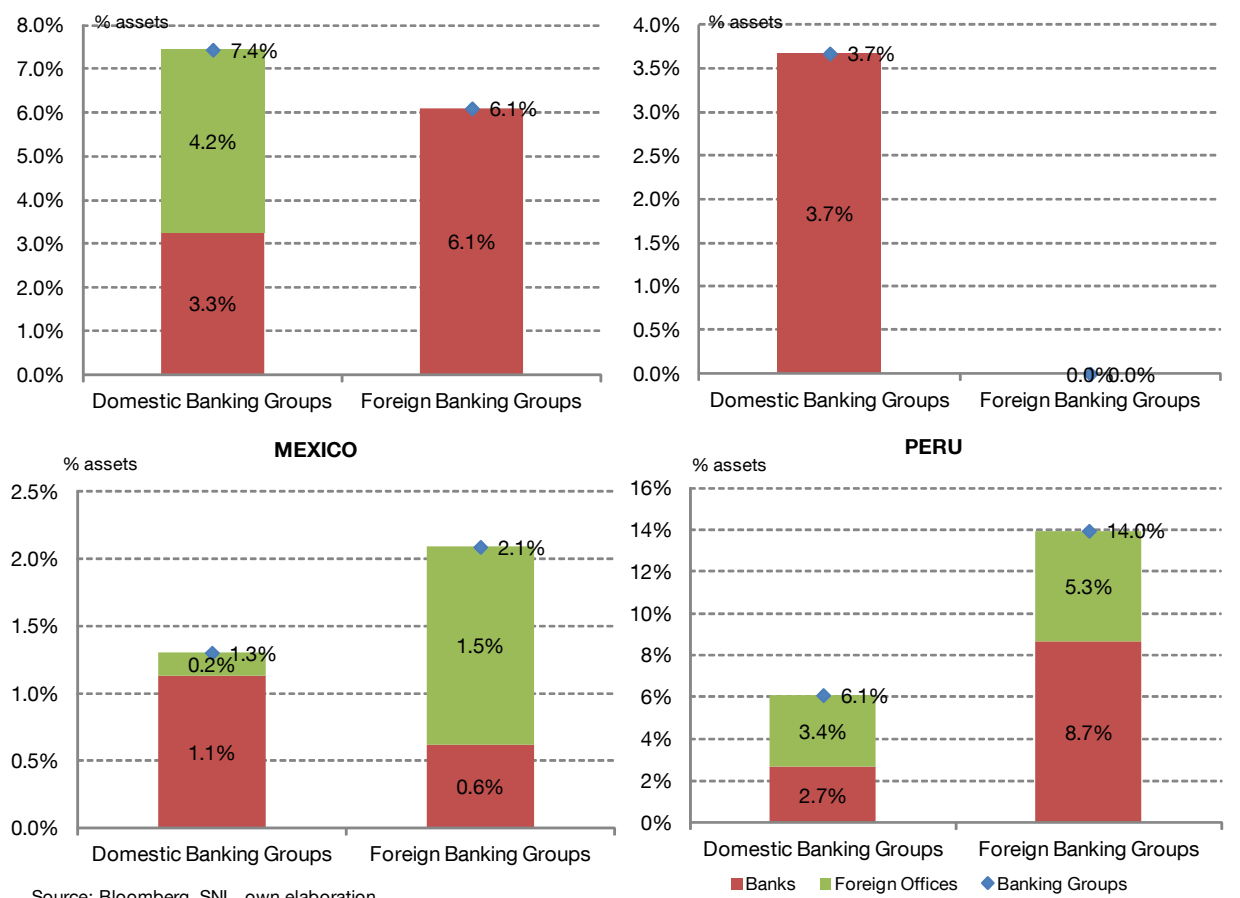


\section{Annex VI: Banks' Liability Structure: By type of bank}

CHART IV. BANKS' LIABILITY STRUCTURE. DOMESTIC VS FOREIGN-OWNED BANKING GROUPS BRAZIL
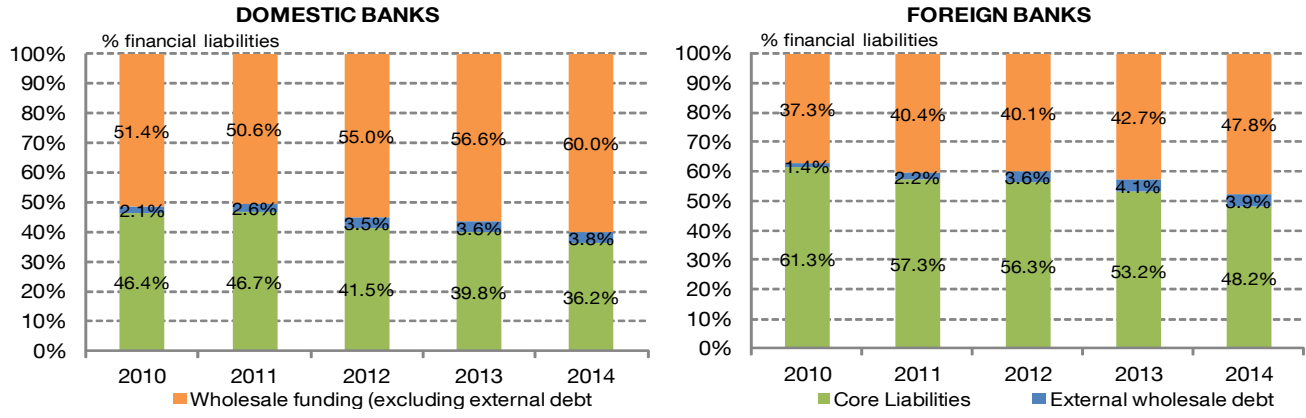

\section{CHILE}
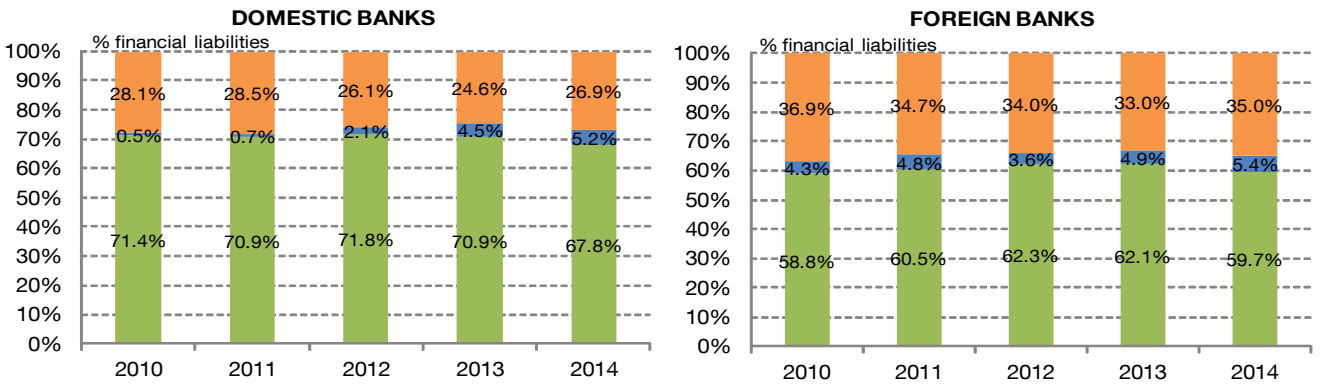

COLOMBIA
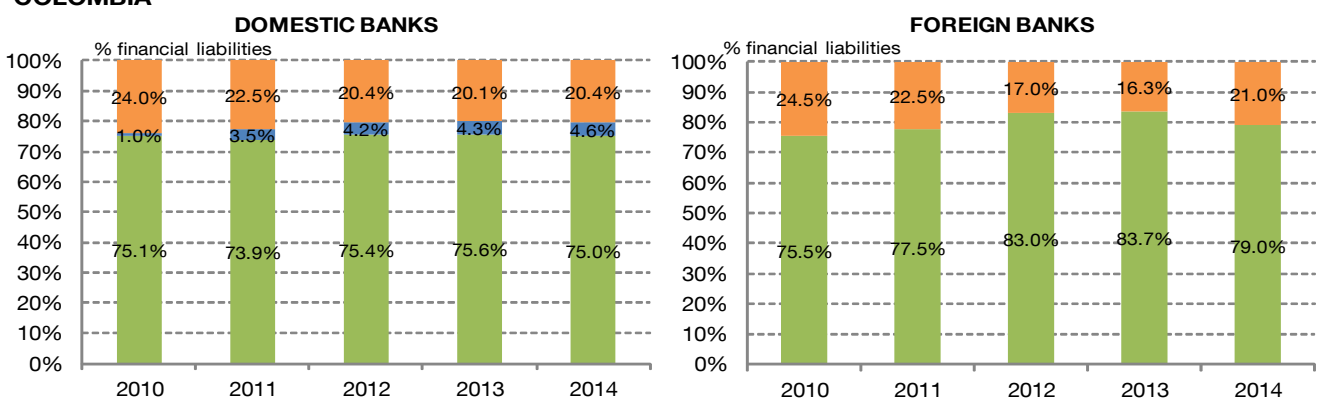

MEXICO
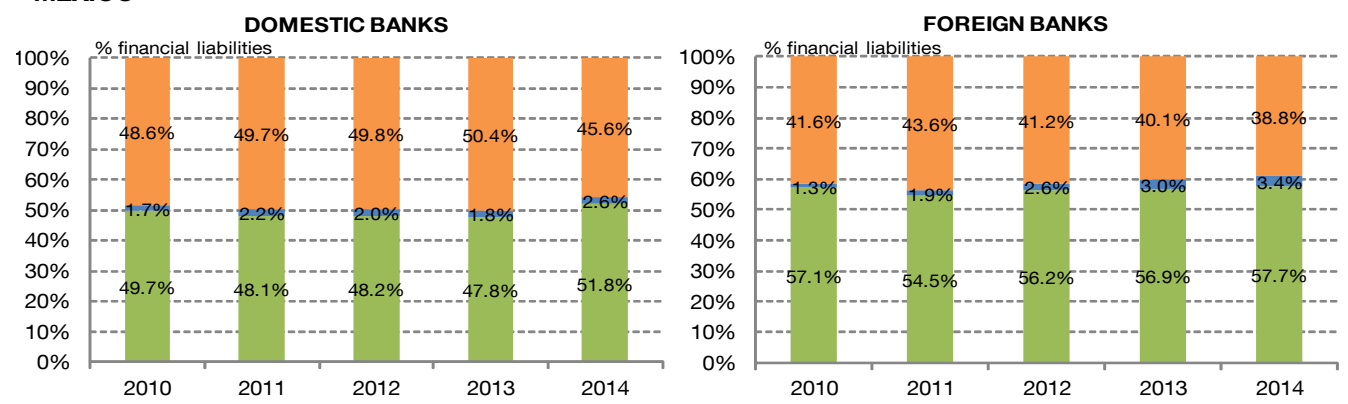

PERU
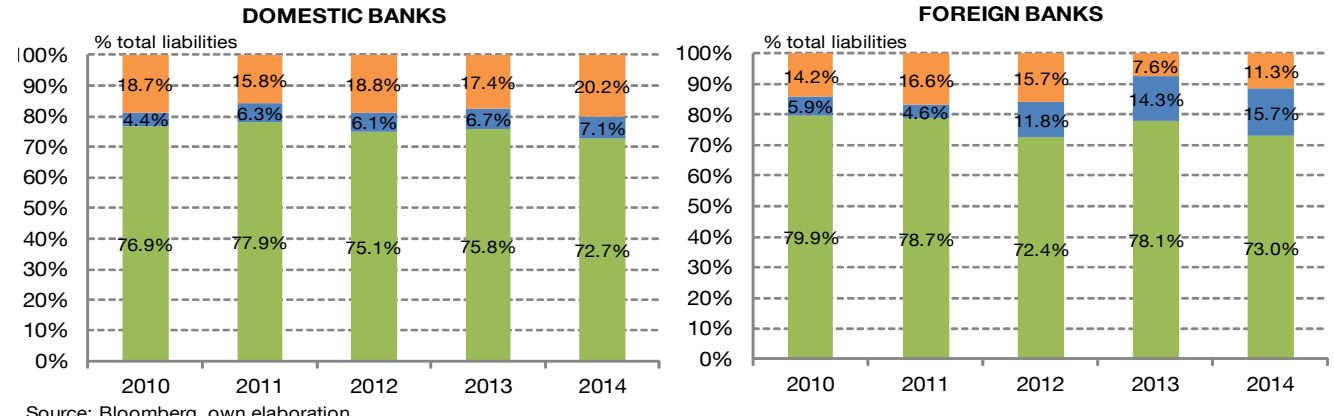

Source: Bloomberg, own elaboration. 


\section{Annex VII. Banks' redemption profiles}

Chart VII presents Latin American banks' redemption profiles per country. The information is provided for all locally-supervised institutions; as well as decomposed by domestic and foreign banking groups.

CHART VII. INTERNATIONAL DEBT MATURITY PROFILE
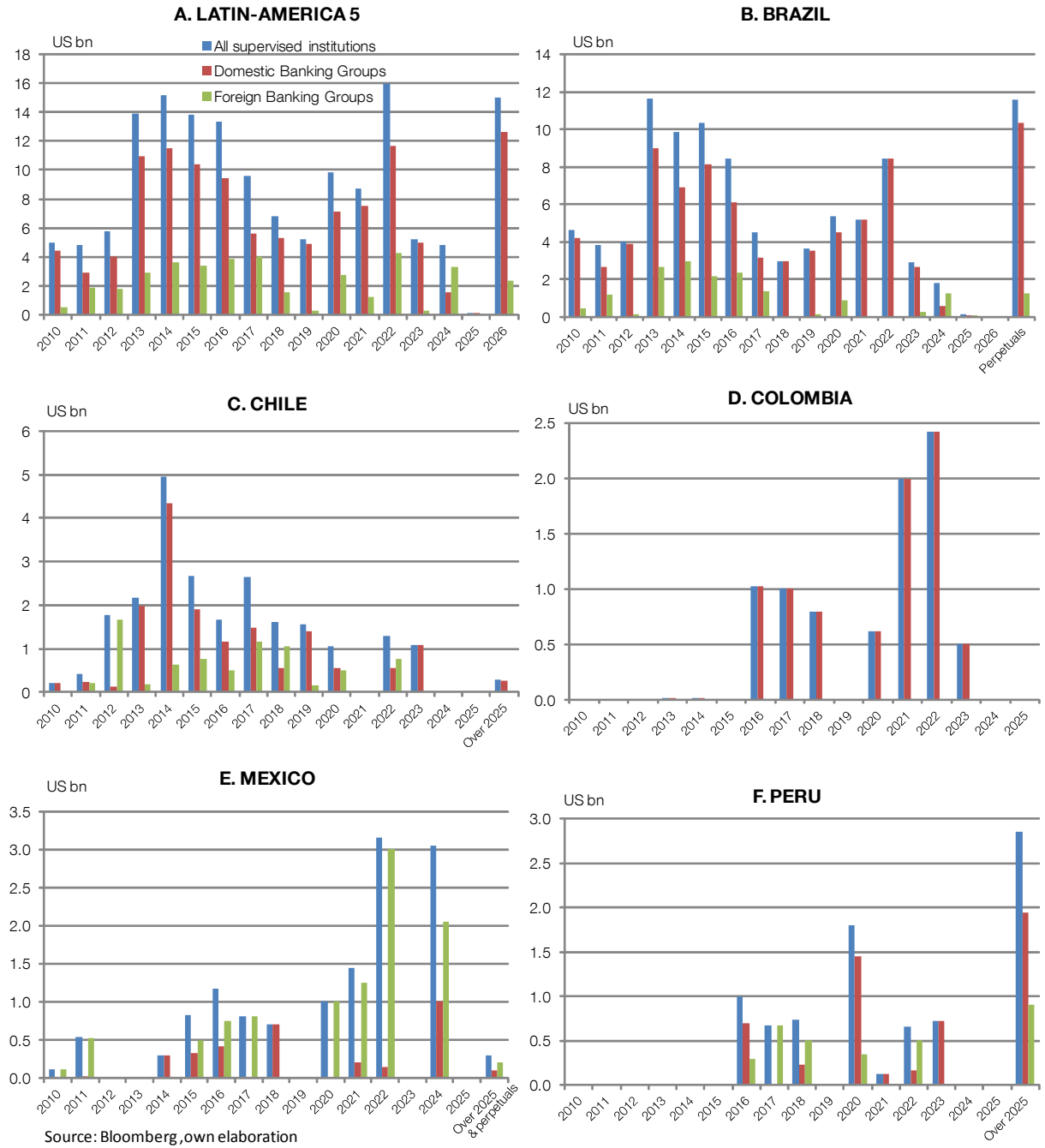


\title{
BANCO DE ESPAÑA PUBLICATIONS
}

\author{
WORKING PAPERS
}

1401 TERESA SASTRE and FRANCESCA VIANI: Countries' safety and competitiveness, and the estimation of current account misalignments.

1402 FERNANDO BRONER, ALBERTO MARTIN, AITOR ERCE and JAUME VENTURA: Sovereign debt markets in turbulent times: creditor discrimination and crowding-out effects.

1403 JAVIER J. PÉREZ and ROCÍO PRIETO: The structure of sub-national public debt: liquidity vs credit risks.

1404 BING XU, ADRIAN VAN RIXTEL and MICHIEL VAN LEUVENSTEIJN: Measuring bank competition in China: a comparison of new versus conventional approaches applied to loan markets.

1405 MIGUEL GARCÍA-POSADA and JUAN S. MORA-SANGUINETTI: Entrepreneurship and enforcement institutions: disaggregated evidence for Spain.

1406 MARIYA HAKE, FERNANDO LÓPEZ-VICENTE and LUIS MOLINA: Do the drivers of loan dollarisation differ between CESEE and Latin America? A meta-analysis.

1407 JOSÉ MANUEL MONTERO and ALBERTO URTASUN: Price-cost mark-ups in the Spanish economy: a microeconomic perspective.

1408 FRANCISCO DE CASTRO, FRANCISCO MARTÍ, ANTONIO MONTESINOS, JAVIER J. PÉREZ and A. JESÚS SÁNCHEZ-FUENTES: Fiscal policies in Spain: main stylised facts revisited.

1409 MARÍA J. NIETO: Third-country relations in the Directive establishing a framework for the recovery and resolution of credit institutions.

1410 ÓSCAR ARCE and SERGIO MAYORDOMO: Short-sale constraints and financial stability: evidence from the Spanish market.

1411 RODOLFO G. CAMPOS and ILIANA REGGIO: Consumption in the shadow of unemployment.

1412 PAUL EHLING and DAVID HAUSHALTER: When does cash matter? Evidence for private firms.

1413 PAUL EHLING and CHRISTIAN HEYERDAHL-LARSEN: Correlations.

1414 IRINA BALTEANU and AITOR ERCE: Banking crises and sovereign defaults in emerging markets: exploring the links.

1415 ÁNGEL ESTRADA, DANIEL GARROTE, EVA VALDEOLIVAS and JAVIER VALLÉS: Household debt and uncertainty: private consumption after the Great Recession.

1416 DIEGO J. PEDREGAL, JAVIER J. PÉREZ and A. JESÚS SÁNCHEZ-FUENTES: A toolkit to strengthen government budget surveillance.

1417 J. IGNACIO CONDE-RUIZ, and CLARA I. GONZÁLEZ: From Bismarck to Beveridge: the other pension reform in Spain.

1418 PABLO HERNÁNDEZ DE COS, GERRIT B. KOESTER, ENRIQUE MORAL-BENITO and CHRISTIANE NICKEL: Signalling fiscal stress in the euro area: a country-specific early warning system.

1419 MIGUEL ALMUNIA and DAVID LÓPEZ-RODRÍGUEZ: Heterogeneous responses to effective tax enforcement: evidence from Spanish firms.

1420 ALFONSO R. SÁNCHEZ: The automatic adjustment of pension expenditures in Spain: an evaluation of the 2013 pension reform

1421 JAVIER ANDRÉS, ÓSCAR ARCE and CARLOS THOMAS: Structural reforms in a debt overhang.

1422 LAURA HOSPIDO and ENRIQUE MORAL-BENITO: The public sector wage premium in Spain: evidence from longitudinal administrative data.

1423 MARÍA DOLORES GADEA-RIVAS, ANA GÓMEZ-LOSCOS and GABRIEL PÉREZ-QUIRÓS: The Two Greatest. Great Recession vs. Great Moderation.

1424 ENRIQUE MORAL-BENITO and OLIVER ROEHN: The impact of financial (de)regulation on current account balances.

1425 MAXIMO CAMACHO and JAIME MARTINEZ-MARTIN: Real-time forecasting US GDP from small-scale factor models.

1426 ALFREDO MARTÍN OLIVER, SONIA RUANO PARDO and VICENTE SALAS FUMÁS: Productivity and welfare: an application to the Spanish banking industry.

1427 JAVIER ANDRÉS and PABLO BURRIEL: Inflation dynamics in a model with firm entry and (some) heterogeneity.

1428 CARMEN BROTO and LUIS MOLINA: Sovereign ratings and their asymmetric response to fundamentals.

1429 JUAN ÁNGEL GARCÍA and RICARDO GIMENO: Flight-to-liquidity flows in the euro area sovereign debt crisis.

1430 ANDRĖ LEMELIN, FERNANDO RUBIERA-MOROLLÓN and ANA GÓMEZ-LOSCOS: Measuring urban agglomeration. A refoundation of the mean city-population size index.

1431 LUIS DIEEZ-CATALÁN and ERNESTO VILLANUEVA: Contract staggering and unemployment during the Great Recession: evidence from Spain. 
1501 LAURA HOSPIDO and EVA MORENO-GALBIS: The Spanish productivity puzzle in the Great Recession.

1502 LAURA HOSPIDO, ERNESTO VILLANUEVA and GEMA ZAMARRO: Finance for all: the impact of financial literacy training in compulsory secondary education in Spain.

1503 MARIO IZQUIERDO, JUAN F. JIMENO and AITOR LACUESTA: Spain: from immigration to emigration?

1504 PAULINO FONT, MARIO IZQUIERDO and SERGIO PUENTE: Real wage responsiveness to unemployment in Spain: asymmetries along the business cycle.

1505 JUAN S. MORA-SANGUINETTI and NUNO GAROUPA: Litigation in Spain 2001-2010: Exploring the market for legal services.

1506 ANDRES ALMAZAN, ALFREDO MARTÍN-OLIVER and JESÚS SAURINA: Securitization and banks' capital structure.

1507 JUAN F. JIMENO, MARTA MARTÍNEZ-MATUTE and JUAN S. MORA-SANGUINEITI: Employment protection legislation and labor court activity in Spain.

1508 JOAN PAREDES, JAVIER J. PÉREZ and GABRIEL PEREZ-QUIRÓS: Fiscal targets. A guide to forecasters?

1509 MAXIMO CAMACHO and JAIME MARTINEZ-MARTIN: Monitoring the world business cycle.

1510 JAVIER MENCÍA and ENRIQUE SENTANA: Volatility-related exchange traded assets: an econometric investigation.

1511 PATRICIA GÓMEZ-GONZÁLEZ: Financial innovation in sovereign borrowing and public provision of liquidity.

1512 MIGUEL GARCÍA-POSADA and MARCOS MARCHETTI: The bank lending channel of unconventional monetary policy: the impact of the VLTROs on credit supply in Spain.

1513 JUAN DE LUCIO, RAÚL MÍNGUEZ, ASIER MINONDO and FRANCISCO REQUENA: Networks and the dynamics of firms' export portfolio.

1514 ALFREDO IBÁÑEZ: Default near-the-default-point: the value of and the distance to default.

1515 IVÁN KATARYNIUK and JAVIER VALLÉS: Fiscal consolidation after the Great Recession: the role of composition.

1516 PABLO HERNÁNDEZ DE COS and ENRIQUE MORAL-BENITO: On the predictability of narrative fiscal adjustments.

1517 GALO NUÑO and CARLOS THOMAS: Monetary policy and sovereign debt vulnerability.

1518 CRISTIANA BELU MANESCU and GALO NUÑO: Quantitative effects of the shale oil revolution.

1519 YAEL V. HOCHBERG, CARLOS J. SERRANO and ROSEMARIE H. ZIEDONIS: Patent collateral, investor commitment and the market for venture lending.

1520 TRINO-MANUEL ÑíGUEZ, IVAN PAYA, DAVID PEEL and JAVIER PEROTE: Higher-order risk preferences, constant relative risk aversion and the optimal portfolio allocation.

1521 LILIANA ROJAS-SUÁREZ and JOSÉ MARÍA SERENA: Changes in funding patterns by Latin American banking systems: how large? how risky?

\section{BANCODEESPAÑA}

Eurosistema
Unidad de Servicios Auxiliares

Alcalá, 48 - 28014 Madrid

E-mail: publicaciones@bde.es www.bde.es 